$$
\text { UNIVERSIDADE DE SÃO PAULO }
$$

ESCOLA DE ENGENHARIA DE SÃO CARLOS DEPARTAMENTO DE ENGENHARIA DE PRODUÇÃO

\title{
DETERMINANTES DA ATIVIDADE EXPORTADORA: UMa ANálise das EMPReSas PaUlistas
}

\author{
PATRICIA BENITES CAVA
}


PATRICIA BENITES CAVA

\section{DETERMINANTES DA ATIVIDADE EXPORTADORA: UMA ANÁlise das EMPRESAs PAULISTAS}

Dissertação apresentada ao Departamento de Engenharia de Produção da Escola de Engenharia de São Carlos, Universidade de São Paulo, como requisito à obtenção do título de Mestre em Engenharia de Produção.

Área de Concentração: Economia, Organizações e Gestão do Conhecimento

Orientador: Prof. Assoc. Aquiles Elie Guimarães Kalatzis

SÃO CARLOS

2010 
AUTORIZO A REPRODUÇĀO E DIVULGAÇĀO TOTAL OU PARCIAL DESTE TRABALHO, POR QUALQUER MEIO CONVENCIONAL OU ELETRÓNICO, PARA FINS DE ESTUDO E PESQUISA, DESDE QUE CITADA A FONTE.

Ficha catalográfica preparada pela Seçăo de Tratamento da Informaçäo do Serviço de Biblioteca - EESClUSP

\footnotetext{
as empresas paulistas / Patricia Benites Cava ; orientador Agu11e8 Blie Guinaräes Kalatzis, -- sāo Carlos, 2010.

D18sertaço 〈Mestrado-Programa de P<8-Graduaço en Engenharia de Produção e Área de Concentraçăo em Bconcmia, organ1zaçese e Gestao do conhecimento) -Escola de Engenharia de sào Carlos da Universidado de sâo Paulo, 2010 .

1. Dconcmia industrial. 2. Determinantes de atividades exportadoras. 3. Industria Paulista. 4. Probit. 5. Logit. I. Titulø,
}

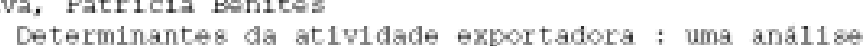


FOLHA DE JULGAMENTO

Candidato(a): Bacharel PATRÍcIA BENITES CAVA.

Dissertação defendida e julgada em 01.10.2010 perante a Comissão Julgadora:

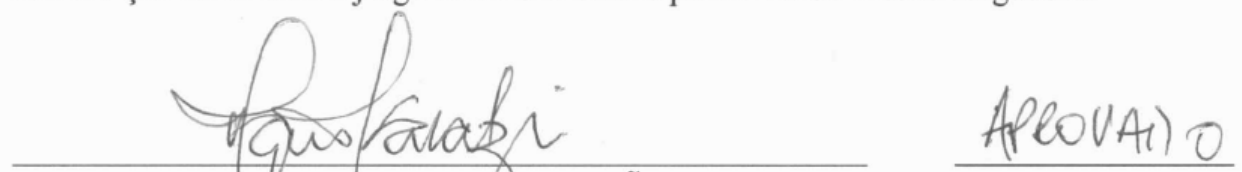

Prof. Associado AQUILES ELIE GUIMARÃES KALATZIS - (Orientador)

(Escola de Engenharia de São Carlos/USP)

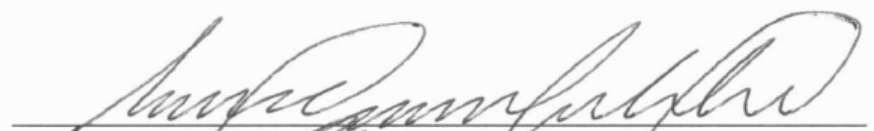

Prof. Dr. ELTON EUSTÁQUIO CASAGRANDE

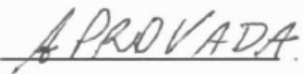

(Universidade Estadual Paulista "Julio de Mesquita Filho"/UNESP/Campus de Araraquara)

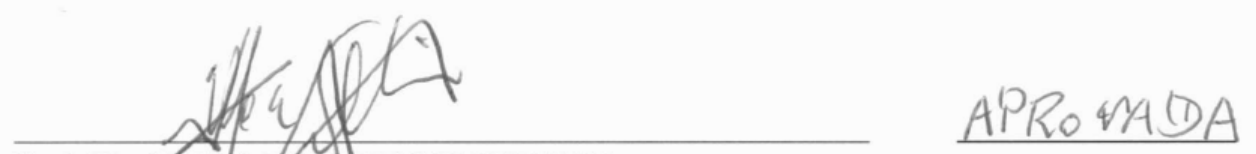

Prof. Titular JOAO WTOR MOCCELLIN

(Escolal Engepharia de São Carlos/USP)
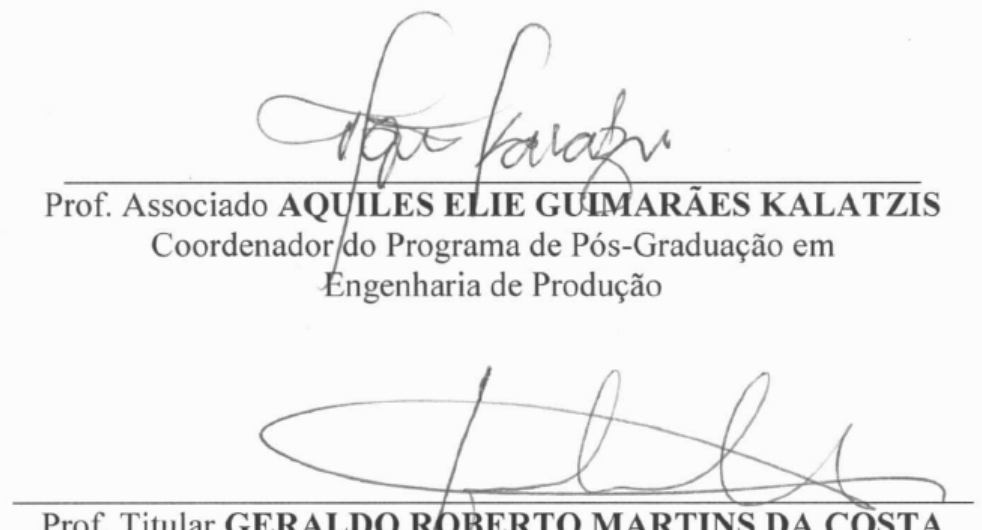

Prof. Titular GERALDO ROBERTO MARTINS DA COOSTA

Presidente da Comissão da Pós-Graduação da EESC 
Dedico este trabalho ...

Ao meu pai, Francisco, pelo amor, pela dedicação incondicional e por me ajudar a tornar os meus sonhos possiveis.

À minha mãe, Aparecida, pelo amor e alegria, por me ensinar a lutar e agradecer pela vida. 


\section{AgRAdeCIMENTOS}

Ao Prof. Assoc. Aquiles Elie Guimarães Kalatzis, meu orientador, pelo incentivo e ensinamentos, por não me deixar desistir nos momentos difíceis, a quem eu admiro e respeito muito.

À minha grande amiga, Camila Bassetto, por todo carinho, pelos incentivos, por estar ao meu lado nos momentos mais difíceis e pela alegria que foi trabalharmos juntas no laboratório.

Ao meu amigo, Lucas Duarte, pelo carinho e amizade, e por me ajudar com a obtenção e organização dos dados.

Às minhas amigas Karina Lumena e Débora Valente, pelo carinho e consideração, por me ajudarem sempre e por tornarem o trabalho muito mais alegre.

À minha amiga Mariana Almeida, por sua amizade e companheirismo, pelas horas de estudo que passamos juntas e à minha amiga Naja, pelo incentivo e por sua amizade.

A todos os meus amigos do laboratório, Flavio, Rodrigo Gigante, Rodrigo Pedra, Marina, Rayani, Lucília e Fernanda, pelos bons momentos que tivemos juntos.

Ao Jen, Marcelo, Pablo e Ricardo, pela amizade e consideração.

Aos meus pais, Aparecida e Francisco, pelo amor e dedicação incondicionais, razão da minha vida.

Ao meu irmão, Vinicius, meu amigo, meu companheiro, a quem eu amo muito, e à minha cunhada, Cristiane, pelo carinho e pela amizade.

À minha avó, Leonor, minha companheira, pelo amor e pela doação. 
À Cristina, pelo amor sincero e por estar sempre ao meu lado.

Às minhas tias, Maria, Mercedes, Marli e Fernanda e meus tios Antonio, Edson e Márcio que sempre foram muito presentes em minha vida e que contribuíram para que eu concluísse este trabalho.

À Capes, pelo auxílio financeiro.

Aos funcionários do Departamento de Engenharia de Produção, pelo empenho e consideração. 


\section{RESUMO}

CAVA, P. B. Determinantes da Atividade Exportadora: Uma análise das empresas paulistas. 2010. Dissertação (Mestrado em Engenharia de Produção) - Escola de Engenharia de São Carlos, Universidade de São Paulo, São Carlos, 2010.

As importantes mudanças macroeconômicas e a abertura comercial ocorridas na década de 90 tiveram como uma de suas conseqüências a reversão dos superávits comerciais. Esse fato gerou uma série de análises sobre a composição das importações e exportações das firmas brasileiras. Com a abertura comercial, as empresas passaram a investir na racionalização de processos produtivos e gerenciais para se tornarem competitivas. A desvalorização da taxa de câmbio, no final da década de 90, implicou no aumento significativo da parcela exportada pela indústria brasileira e mudanças ocorreram na estratégia competitiva da indústria. A análise destas diferenças e do caminho percorrido por elas contribuem para um melhor mapeamento e discussão das condições competitivas da indústria no mercado internacional. Diante desse contexto, o objetivo do presente trabalho é identificar os principais determinantes da atividade exportadora de indústrias paulistas. Para alcançar o objetivo proposto, utilizou-se dados referentes aos anos de 1996 e 2001 de indústrias paulistas, disponíveis na Pesquisa da Atividade Econômica Paulista (PAEP), realizada pela Fundação Estadual de Análise de Dados (SEADE). Os dois períodos de análise apresentam características distintas no que se refere ao contexto econômico, o que pode ter acarretado na adoção de estratégias competitivas diferentes pelas empresas. Para a estimação dos parâmetros das variáveis explicativas adotou-se os métodos Probit e Logit. Os resultados da pesquisa permitiram identificar o tamanho da empresa, participação estrangeira no capital, idade, importação e inovação tecnológica como determinantes da atividade exportadora das indústrias paulistas. A produtividade do trabalho e a qualificação do trabalho apresentaram resultados distintos para os anos de 1996 e 2001.

Palavras-chave: Determinantes da atividade exportadora, Indústria Paulista, Probit, Logit. 


\section{ABSTRACT}

CAVA, P. B. Determinantes da Atividade Exportadora: Uma análise das empresas paulistas. 2010. Dissertação (Mestrado em Engenharia de Produção) - Escola de Engenharia de São Carlos, Universidade de São Paulo, São Carlos, 2010.

Major macroeconomic changes and trade liberalization occurred in the $90 \mathrm{~s}$ had as one of their consequences the reversal of trade surpluses. This has raised a number of reviews on the composition of imports and exports of Brazilian firms. With the trade liberalization, companies started to invest in the rationalization of production processes and management in order to become competitive. The devaluation of the exchange rate in the end of the $90 \mathrm{~s}$, resulted in significant increase in the share exported by the Brazilian industry and changes occurred in the competitive strategy of the industry. The analysis of these differences contributes to a better mapping and discussion of competitive conditions in the industry internationally. In this context, the objective of this study is to identify the main determinants of export activity of Paulistas industries. To achieve the proposed objective, we used data for the years 1996 and 2001 from Paulistas industries, available on the Pesquisa da Atividade Econômica Paulista (PAEP) held by the Fundação Estadual de Análise de Dados (SEADE). These periods have different characteristics with regard to the economic context, which may have led to the adoption of different competitive strategies by companies. For the estimation of the explanatory variables we adopted the methods Probit and Logit. The research results have identified the company size, foreign ownership, age, import and technological innovation as determinants of export activity of the Paulistas industries. The labor productivity and skilled labor showed different results for the years 1996 and 2001.

Keywords: Determinants of export activity, Paulista Industry, Probit, Logit. 


\section{Lista de QUAdRos}

Quadro 1 - Variáveis utilizadas na elaboração do modelo .67 


\section{LiSTA DE TABELAS}

Tabela 1 - Características das Firmas Inovadoras e Não Inovadoras............................71

Tabela 2 - Características da Firmas de alto e baixo grau tecnológico........................73

Tabela 3 - Resultados da estimação do modelo Probit para os anos de 1996 e 2001.76

Tabela A - Características de micro empresas......................................................... 90

Tabela B - Características de pequenas empresas.................................................. 90

Tabela C - Características de médias empresas...................................................... 91

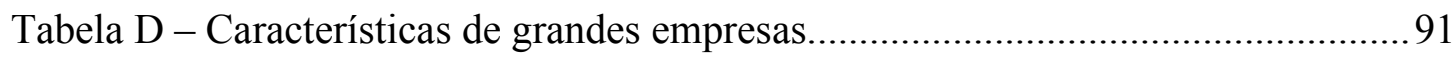

Tabela E - Resultados da estimação do modelo Probit para os anos de 1996 e 2001

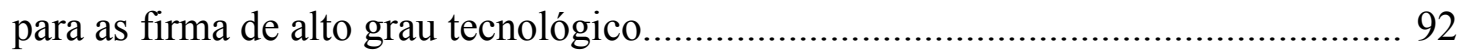

Tabela F - Resultados da estimação do modelo Probit para os anos de 1996 e 2001 para as firma de baixo grau tecnológico.................................................................. 93 


\section{LiSTA DE FigurAS}

Figura 1a - Distribuição das firmas por porte 69

Figura $1 b$ - Distribuição das firmas por porte 


\section{LiSTA DE SÍMBOLOS}

$\begin{array}{ll}F & \text { Função de distribuição acumulada logística padrão } \\ \phi & \text { Função de distribuição acumulada normal padrão } \\ P & \text { Probabilidade } \\ x^{\prime} S & \text { Variáveis explicativas } \\ \beta^{\prime} S & \text { Parâmetros das variáveis explicativas } \\ \mathrm{Y} & \text { Variável dependente dos modelos }\end{array}$




\section{SUMÁRIO}

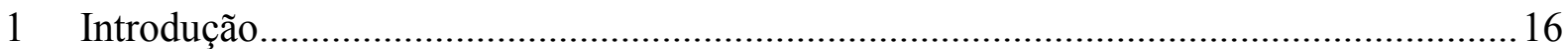

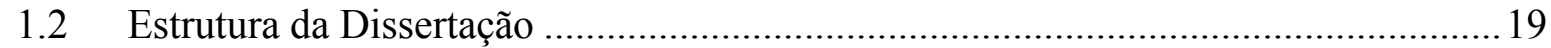

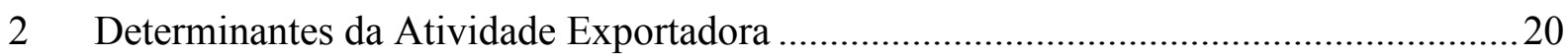

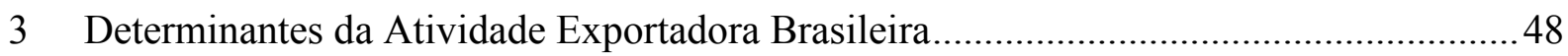

4 Análise dos Determinantes da Atividade Exportadora Paulista.....................................60

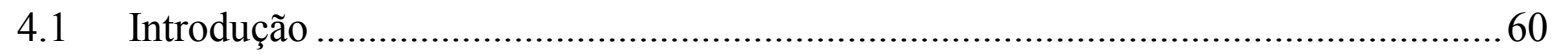

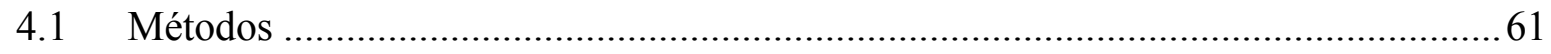

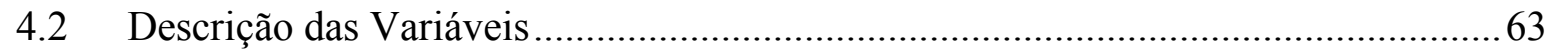

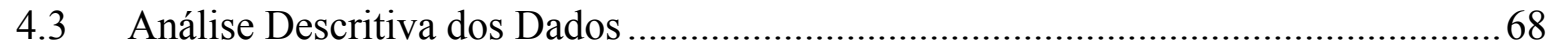

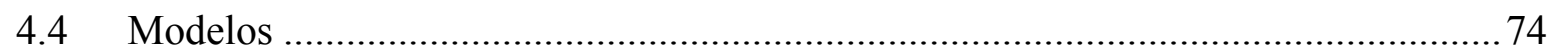

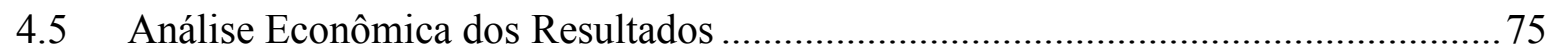

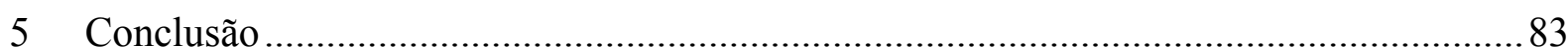




\section{INTRODUÇÃO}

O processo de abertura comercial e importantes mudanças macroeconômicas ocorridas no Brasil na década de 90 foram responsáveis por uma reestruturação na indústria brasileira. Após décadas de economia fechada e forte participação do Estado na produção de bens e serviços ocorriam diversos fatores como a redução de barreiras comerciais tarifárias e nãotarifárias, o estabelecimento do Mercosul, a privatização de companhias, com novas regras ao investimento estrangeiro, reformas no sistema financeiro e de seguridade social. Dentre as mudanças ocorridas neste período, a que impactou mais fortemente sobre a indústria foi a abertura comercial. 
Nos primeiros anos da década de 90 houve uma intensa e rápida reestruturação, em que empresas investiram na racionalização de processos produtivos e gerenciais e na redução de linhas de produtos para terem condições de competir neste novo ambiente. Segundo De Negri e Salerno (2005), no início dos anos 90, início do processo de abertura comercial, a indústria brasileira estava acomodada e sem estímulos para inovação e diferenciação de produtos. Isto foi uma das causas da dificuldade para sua inserção no comércio internacional. Entre os anos de 1995 e 1997 houve um aumento do investimento das empresas em capital fixo. A partir de 1997, os investimentos voltados à eficiência começaram a reduzir sua participação e aqueles voltados para renovação de produtos e ampliação de plantas começaram a surgir de forma freqüente. Na estrutura da produção industrial e exportação houve aumento da participação de setores intensivos em recursos naturais e redução de setores intensivos em trabalho. Quanto ao nível tecnológico, tanto na estrutura da produção industrial quanto nas exportações houve aumento da participação de produtos de nível tecnológico médio e redução na participação de setores de baixo nível tecnológico.

Após a desvalorização cambial em 1999 houve um aumento significativo da parcela exportada na indústria brasileira. Contudo, Comin (2003, p.27) argumenta que "o direcionamento da estrutura produtiva e, sobretudo da pauta de exportações para os produtos e países menos nobres do comércio mundial na verdade ampliou ainda mais a vulnerabilidade externa da economia". De Negri e Salerno (2005) argumentam que a diferenciação de produtos e processos e a inovação tecnológica são elementos chave para a competitividade da indústria no ambiente mundial, mas a indústria brasileira teve dificuldade de inserção por não estar preparada para isto.

Com o objetivo de compreender melhor o comportamento exportador, a presente pesquisa concentrou-se no entendimento dos determinantes da atividade exportadora e, com isto, buscou evidências para o direcionamento e avaliação de políticas e tomada de decisão. 
Desta forma, o objetivo principal do trabalho foi identificar, a partir dos dados da Pesquisa da Atividade Econômica Paulista (PAEP) de 1996 e 2001, quais são os principais determinantes da atividade exportadora de indústrias paulistas. Como objetivo secundário, esta pesquisa pretendeu identificar se diferentes proxies utilizadas para representar inovação poderiam apresentar resultados distintos. Para avaliar o papel da inovação tecnológica foram propostas três diferentes medidas: realização interna de pesquisa e desenvolvimento, registro de patentes e realização de inovação, conforme argumentado em Wakelin (1997).

A contribuição deste trabalho está na análise do registro de patentes como determinante do comportamento exportador da indústria paulista. As variáveis inovação tecnológica e pesquisa e desenvolvimento são mais comuns em estudos sobre o comportamento exportador. Entretanto, estudos que realizam uma comparação de variáveis tecnológicas e que incluem a variável registro de patentes são escassos, principalmente se forem considerados estudos brasileiros.

A análise empírica foi realizada a partir de dados de indústrias paulistas. Os dados utilizados têm como base as informações disponíveis na Pesquisa da Atividade Econômica Paulista (PAEP) realizada em 1996 e 2001 pela Fundação Estadual de Análise de Dados (SEADE). A amostra do ano de 1996 é composta por 9.298 firmas industriais, entre elas 1.704 exportadoras e 7.594 firmas não exportadoras. A amostra do ano de 2001 é composta por 9.733 firmas industriais, 2.252 exportadoras e 7.481 não exportadoras. Para a estimação dos parâmetros das variáveis explicativas foram utilizados os métodos Probit e Logit.

No ano de 1996, período em que a economia brasileira tornou-se de fato uma economia aberta, a indústria estava em um período caracterizado pelo aumento dos investimentos em capital fixo e eficiência. Contudo, as intenções de investimento em renovação de produtos e expansão de plantas começavam a aparecer nas pesquisas. No ano de 2001 o câmbio já havia desvalorizado, havia uma crise energética e o cenário 
macroeconômico apresentava-se com novos desafios. Além disto, no período entre 1999 e 2001 houve grande perturbação externa. Assim, os dois períodos de coleta dos dados apresentaram características distintas e as empresas, possivelmente, adotavam estratégias competitivas distintas. A análise destas diferenças e do caminho percorrido pelas indústrias contribui para um melhor mapeamento e discussão das condições competitivas da indústria no mercado internacional.

\subsection{ESTRUTURA DA DiSSERTAÇÃO}

Este trabalho está estruturado em 5 capítulos, incluindo esta introdução. O capítulo 2 apresenta uma revisão de literatura a respeito dos determinantes da atividade exportadora. O capítulo 3 apresenta estudos sobre os determinantes da atividade exportadora brasileira. No capítulo 4 apresentam-se os métodos utilizados, a descrição das variáveis, a análise descritiva dos dados, a especificação do modelo, a classificação a ser utilizada e a análise econômica dos resultados. Por fim, as conclusões são apresentadas no capítulo 5 . 


\section{DETERMINANTES DA ATIVIDADE EXPORTADORA}

Este capítulo contém uma revisão de literatura sobre os determinantes da atividade exportadora. A literatura que trata dos determinantes da atividade exportadora sob o ponto de vista microeconômico ganhou maior destaque na década de 90 . O mercado internacional expõe as empresas a uma competição mais acirrada e propicia o contato com melhores práticas internacionais. Em virtude disto, estudos realizados em diversos países investigaram quais características das firmas determinam o comportamento exportador e quais os benefícios advindos do contato destas firmas com o mercado externo.

Roberts e Tybout (1997) utilizaram um conjunto de 650 firmas no período de 1981 a 1989 para avaliar se a decisão de exportar é influenciada pela experiência anterior no mercado 
exportador para empresas da Colômbia. Os autores utilizaram um modelo Probit dinâmico para avaliar o papel das características da firma e dos custos de entrada no mercado externo sobre o comportamento exportador. O modelo considerou um efeito temporal, para refletir condições de mercado, taxa de câmbio, políticas de comércio, custos de entrada no mercado internacional e que, portanto, afetariam todas as empresas. Os autores expuseram que firmas que já exportaram incorreram em custos para entrar no mercado internacional e, por este motivo, elas seriam mais prováveis de exportar em períodos posteriores do que empresas que nunca exportaram. A fim de avaliar se a exportação em períodos anteriores contribui para explicar a atividade exportadora do período atual, o modelo considerou se a firma exportou em algum dos três anos anteriores ao atual ${ }^{1}$. Segundo os autores, estas variáveis considerariam a importância dos custos de inserção no mercado externo. Para identificar o papel da estrutura de propriedade da firma, o papel da região onde a firma está localizada e da indústria da firma, foram utilizadas variáveis $d u m m y^{2}$. Com o objetivo de captar a atratividade do mercado doméstico contra a atratividade do mercado estrangeiro foram incluídas a taxa de preços externos sobre preços domésticos e a taxa de salários, ambas defasadas em um ano e medidas em logaritmo. $\mathrm{O}$ estoque de capital e idade da firma representaram eficiência e também foram medidos em logaritmo e defasados em um ano .

Os resultados indicaram que o tamanho da empresa, medido pelo estoque de capital, e a participação estrangeira no capital apresentaram impacto positivo para explicar a probabilidade de exportar. O tamanho da firma possivelmente estaria relacionado aos ganhos de escala e a participação estrangeira poderia indicar transferência de capital e conhecimento. A experiência em anos anteriores no mercado externo contribuiu de forma positiva e

\footnotetext{
${ }^{1}$ Para o ano t, por exemplo, $\mathrm{t}=1988$, foi avaliado se a empresa exportou em 1987, 1986 e 1985.

${ }^{2}$ Variável dummy é uma variável fictícia que pode ter valor 0 ou 1. Ela indica a ocorrência ou não de algum fato. Por exemplo, a variável dummy pode assumir valor 0 se a empresa está localizada no litoral e assumir o valor 1 se a empresa está localizada no interior.
} 
significativa para explicar a decisão de exportar, indicando que se uma empresa exportou em pelo um dos três anos anteriores ela é mais provável de exportar do que uma empresa que não exportou em anos anteriores. A experiência em anos anteriores estaria capturando o efeito dos custos fixos de entrada no mercado externo. Os custos fixos de entrada no mercado externo, que incluem custos de adequação de produtos ao mercado externo, custos de embalagem e estabelecimento de canais de comercialização com o mercado exportador, afetam negativamente as exportações. Desta forma, quanto maiores os custos para ingressar no mercado internacional, menor a probabilidade de uma empresa exportar. Os resultados do estudo também sugeriram que após uma ausência de dois anos do mercado externo, os custos de reentrada no mercado internacional são iguais àqueles custos incorridos por novos exportadores.

Ainda segundo Roberts e Tybout (1997), a taxa de salário e taxa de preços externos sobre preços domésticos não foram significativas para explicar a probabilidade de exportar. Quanto à localização, firmas situadas em cidades portuárias ou próximas à costa são mais prováveis de exportar. A idade da firma exerceu impacto positivo e significativo sobre a probabilidade de exportar, sugerindo que empresas mais maduras são mais prováveis de entrar no mercado externo.

Clerides, Lauch e Tybout (1998) analisaram relações de causalidade entre produtividade e exportações para firmas da Colômbia, México e Marrocos. Os autores avaliaram se as firmas tornam-se exportadoras por serem mais eficientes ou se elas aprendem a ser mais eficientes por tornarem-se exportadoras. Para a avaliação das firmas colombianas foi utilizada uma base de dados que considera firmas com pelo menos 10 empregados no período de 1981 a 1991. No México foram utilizadas informações das 2800 maiores firmas no período de 1986 a 1990. Para o Marrocos, os dados cobriram quase todas as firmas com pelo 
menos 10 empregados de 1984 a 1991. Os autores compararam a trajetória de custos de empresas antes e depois de entrarem no mercado externo bem como após sua saída.

Para firmas da Colômbia e México, os autores notaram que houve uma redução nos custos das empresas pouco antes de entrarem no mercado externo e um aumento antes de sua saída. Contudo, não foram encontradas evidências de que a entrada no mercado externo reduza estes custos. As firmas do Marrocos apresentaram comportamento diferente das anteriores. Houve um declínio nos custos das empresas antes da entrada no mercado externo. Quanto à trajetória dos custos ao sair do mercado externo, após dois anos decorridos de sua saída, estas firmas apresentaram custos mais elevados que a indústria de modo geral. Considerando a redução dos custos antes de a empresa tornar-se exportadora, os autores sugeriram que há um processo de auto-seleção, ou seja, que as firmas mais produtivas tornemse exportadoras. Por outro lado, como não houve redução de custos após a entrada no mercado externo, os autores sugeriram que para as empresas da Colômbia, México e Marrocos, não há efeito de aprendizagem decorrente da atividade exportadora.

Lefebvre, Lefebvre e Borgaut (1998) analisaram o papel da tecnologia na atividade exportadora utilizando informações de 101 empresas do Canadá para o ano de 1995, sendo as mesmas registradas em arquivos governamentais como firmas que possuem atividades formais de pesquisa e desenvolvimento. Os autores explicaram que a utilização de medidas de pesquisa e desenvolvimento (P\&D) é limitada e que “[...] mais investimentos em atividades de P\&D, embora crucial, não são suficientes para ganhar vantagem competitiva nos mercados exportadores sem também confiar em outras capacidades relacionadas à P\&D” (LEFEBVRE; LEFEBVRE; BORGAUT, 1998, p.365). Estas capacidades podem ser o nível de investimento em capital humano, como por exemplo, pessoal técnico e científico qualificado, as fontes de informação para atividades de $\mathrm{P} \& \mathrm{D}$, parceiros ou colaboradores externos. 
O estudo avaliou a intensidade exportadora, em que a variável dependente é a proporção das vendas que é exportada, por meio de uma regressão Tobit. Foram estimadas duas regressões de acordo com o país de destino das exportações. Assim, foi estudada a relação entre as variáveis explicativas e a intensidade das exportações direcionadas ao mercado norte americano e a relação das variáveis explicativas e a intensidade das exportações direcionadas ao restante do mercado mundial.

Os resultados apontaram que para as exportações direcionadas à América do Norte, tamanho da empresa apresenta impacto positivo e significativo sobre a intensidade exportadora. A variável tamanho não apresentou-se significativa quando o destino das exportações é o mercado global. As variáveis intensidade do conhecimento tecnológico, estratégias de P\&D direcionadas a pesquisa básica, melhoria nos produtos existentes e em ativos científicos/tecnológicos apresentaram impacto positivo e significativo sobre as exportações. Foram avaliadas as fontes de informação utilizadas na inovação, como informações obtidas de clientes, concorrentes e outros. Das fontes de informação avaliadas, apenas as fontes de informação interna/clientes apresentaram impacto positivo e significativo para explicar a intensidade exportadora. Contudo, os resultados se alteraram quando o destino das exportações é o mercado global. Nesta situação, exerceram impacto positivo para explicar a intensidade das exportações as estratégias de $\mathrm{P} \& \mathrm{D}$ direcionadas ao desenvolvimento de produtos, pesquisa aplicada e melhoria de produtos existentes. As variáveis que representaram as formas de colaboração com $\mathrm{P} \& \mathrm{D}$, como agências públicas, clientes e concorrentes, impactaram de forma positiva e significativa para explicar a intensidade das exportações. Das fontes de informação da inovação avaliadas, as agências públicas e P\&D interno apresentaram impacto positivo e significativo para explicar a intensidade exportadora.

Wakelin (1998) avaliou a importância das características da firma bem como do setor da firma para explicar a probabilidade de exportar e o nível de exportação e apontou que os 
determinantes são diferentes para empresas inovadoras e não inovadoras ${ }^{3}$. O conjunto de dados utilizados no trabalho é composto por 320 firmas do Reino Unido para o período de 1988 a 1992. A autora explicou que para as firmas do Reino Unido, o uso de inovações produzidas no setor eleva a probabilidade de uma firma exportar, mas não o seu nível de exportação. Além disto, a quantidade de inovações produzidas pela empresa e pelo setor impacta de forma positiva na probabilidade de exportar, mas esta variável não apresentou-se significativa para explicar a intensidade das exportações ${ }^{4}$.

Neste estudo, o tamanho da firma impactou de forma positiva e significativa tanto na probabilidade quanto no nível de exportação, enquanto a variável tamanho da firma na forma quadrática apresentou sinal negativo e significativo em ambos os casos. O salário médio, o qual estaria representando o nível de habilidade dos funcionários, apresentou-se positivo e significativo para explicar a probabilidade e intensidade das exportações. Entretanto, quando as firmas são classificadas em firmas inovadoras e firmas não inovadoras, a variável salário apresentou-se com sinal positivo e significativo para firmas não inovadoras e, negativo, mas não significativo, para as firmas inovadoras. A autora explica que uma relação positiva entre salário e atividade exportadora para as firmas não inovadoras pode indicar que altos níveis de salário estão relacionados com níveis mais elevados de habilidade e que, portanto, elevaria a probabilidade de firmas não inovadoras exportarem.

Os custos unitários do trabalho não se mostraram significativos para explicar a probabilidade e intensidade das exportações quando foram analisadas todas as firmas. Entretanto, quando a amostra é classificada entre firmas inovadoras e firmas não inovadoras, os custos unitários do trabalho são negativos e significativos para empresas não inovadoras,

\footnotetext{
${ }^{3}$ Para explicar a probabilidade de uma empresa exportar foi utilizado um modelo Probit, em que a variável dependente indica se a empresa exporta ou não, ou seja, variável binária. Para explicar a intensidade das exportações foi utilizado um modelo Tobit, em que a variável dependente é a proporção do faturamento resultante das exportações.

${ }^{4}$ Para Wakelin (1998), as inovações produzidas no setor foram consideradas a oportunidade tecnológica do setor, enquanto que o uso de inovações foram considerados spill-overs de inovação de outras firmas.
} 
mas positivos e significativos para as inovadoras. De acordo com a autora, este resultado pode estar relacionado à qualidade dos produtos exportados pelas firmas inovadoras, os quais seriam menos sensíveis ao preço. O trabalho ainda aponta que firmas maiores e inovadoras são mais prováveis de entrar no mercado exportador. Entretanto, entre as pequenas firmas, as inovadoras são menos prováveis de exportar, indicando algum tipo de vantagem no mercado interno. Para o estudo de Wakelin (1998), a variável inovação mostrou-se positiva e significativa para explicar a probabilidade de exportar, mas não foi significativa para explicar o quanto a firma exporta. A intensidade de capital apresentou-se positiva e significativa tanto para explicar a probabilidade quanto a intensidade das exportações.

Sterlacchini (1999) analisou a relação entre comportamento exportador e medidas de inovação diferentes de $\mathrm{P} \& \mathrm{D}$ em pequenas empresas italianas que não pertencem às indústrias

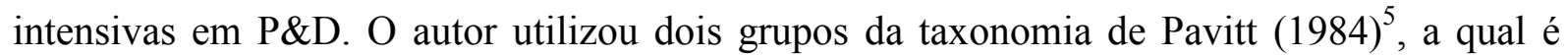
composta por quatro grupos de firmas: firmas dominadas pelos fornecedores (supplier dominated), firmas intensivas em escala (scale intensive), firmas de base tecnológica (science based) e fornecedores especializados (specialized supliers) (ARAUJO, 2005; DIJK, 2002). Para o estudo foram utilizados dados de firmas que pertencem às categorias de firmas dominadas pelos fornecedores (supplier dominated) e fornecedores especializados (specialized supliers) para o ano de 1997. As informações foram obtidas por meio de entrevistas.

No texto, o autor explica que para pequenas firmas, muitas vezes, não há um departamento formal de $\mathrm{P} \& \mathrm{D}$, o que subestimaria o impacto das atividades de inovação na atividade exportadora. Para representar inovação, além de uma variável dummy que identifica se a firma inova ou não, foram incluídas três variáveis: o nível tecnológico do estoque de

5 PAVITT, K. Sectoral patterns of technical change: towards a taxonomy and a theory. Research Policy, v. 13, p. $343-373,1984$. 
capital, os gastos com design, engenharia e triagem de produção e os bens de capital inovativos, que foram obtidos por meio dos custos relativos da compra de bens para inovação ${ }^{6}$. Além das variáveis de inovação, foram considerados no modelo o tamanho da firma, representado pela receita operacional líquida em 1996 e a filiação da empresa a um grupo de negócios, identificada por variável dummy. As firmas que vendiam a outra empresa uma parcela maior que $60 \%$ de suas vendas foram classificadas como subcontratadas.

No estudo de Sterlacchini (1999), os dados foram analisados de três formas diferentes. A primeira forma de análise considerou todas as firmas da amostra. $\mathrm{Na}$ segunda forma foram consideradas apenas as firmas inovadoras e, por fim, na terceira forma foram consideradas apenas as firmas independentes, uma vez que havia grande número de firmas subcontratadas na amostra. Para a primeira análise, os resultados apontaram que a variável dummy que representa inovação e os gastos com design, engenharia e triagem de produção exercem impacto positivo e significativo para explicar a intensidade das exportações. Os bens de capital adquiridos e o nível tecnológico do estoque de capital não foram significativos para explicar a intensidade das exportações. O parâmetro da variável tamanho obteve sinal positivo e, o parâmetro da variável na forma quadrática, passou a ser negativo, sendo ambos significativos para explicar a intensidade das exportações. A variável dummy que indica se a firma é subcontratada também apresentou-se negativa e significativa para explicar a intensidade das exportações. Na segunda análise, em que constam apenas as firmas inovadoras, os resultados são semelhantes ao primeiro caso quando se analisa a intensidade das exportações. Entretanto, nenhuma variável relacionada à inovação apresentou-se significativa para explicar a probabilidade de exportar. Na terceira análise, em que são consideradas apenas as firmas independentes, das variáveis que representam inovação, apenas

\footnotetext{
${ }^{6}$ Para avaliar o nível tecnológico do estoque de capital da firma o autor utilizou um critério para avaliar máquinas e dispositivos utilizados em cada fase de produção, como pode ser observado no Apêndice A do referido trabalho.
} 
a variável dummy que representa inovação e os gastos com design, engenharia e triagem de produção apresentaram-se positivos e significativos para explicar a intensidade das exportações. No entanto, o nível tecnológico do estoque de capital, os gastos com design, engenharia e triagem de produção e os bens de capital inovativos apresentaram-se positivos e significativos para explicar a probabilidade de exportar. Em nenhuma das análises a variável filiação da empresa a um grupo de negócios apresentou-se significativa.

Bernard e Jensen (1999) argumentaram que há um crescente número de trabalhos empíricos que apontam que firmas exportadoras possuem melhor desempenho que firmas não exportadoras. $\mathrm{O}$ estudo utilizou informações de empresas americanas para os anos de 1984 a 1992 com o objetivo de investigar se indicadores de desempenho de firmas exportadoras, como vendas, salários e produtividade são superiores aos indicadores de firmas não exportadoras mesmo antes de elas entrarem no mercado internacional. Outra questão abordada no estudo é se a atividade exportadora contribui para a melhoria destes indicadores de desempenho. Para isto, o estudo comparou indicadores de salário, produtividade e vendas antes e após a entrada das firmas no mercado internacional.

Os autores identificaram que firmas que se tornam exportadoras são maiores, possuem produtividade do trabalho superior e pagam maiores salários que as firmas não exportadoras antes de entrarem no mercado externo. Desta forma, futuros exportadores possuem indicadores de desempenho superiores antes de iniciarem a atividade exportadora, o que sugere um processo de seleção das firmas mais eficientes. Assim, firmas mais eficientes teriam melhores condições de arcar com os custos de entrada no mercado internacional que firmas menos eficientes. Os autores observaram que, com o início da atividade exportadora, as empresas obtiveram maior probabilidade de sobrevivência e apresentaram evidências de crescimento do tamanho da firma, mas apenas em curto prazo. No longo prazo, contudo, os resultados indicaram que o crescimento da produtividade do trabalho e da produtividade total 
dos fatores poderia ser até menor para as firmas exportadoras que para as não exportadoras. Assim, não foi possível afirmar que as exportações contribuem para a melhoria dos indicadores de desempenho da firma. Em adição, os autores comentam que firmas que páram de exportar apresentam indicadores de performance com crescimento inferior aos indicadores de firmas não exportadoras.

Bishop (2001) avaliou os determinantes das exportações para as firmas da Rússia, Bielorrússia e Ucrânia para o ano de 1997. Em sua análise o autor utilizou de regressão logística e regressão linear. O modelo elaborado considerou a parcela das vendas que foi exportada no ano de 1995 e o declínio do produto real da indústria. Para representar o tamanho da firma foi utilizado o número de empregados e a estrutura de propriedade da firma foi identificada por meio da parcela da empresa que é de propriedade de funcionários e pela parcela da empresa que é de propriedade estrangeira. Foram avaliados ainda o investimento e a existência de parceiros estrangeiros.

As estimativas obtidas para o parâmetro da variável tamanho da firma obtiveram sinal positivo e foram significativas para explicar a probabilidade e a intensidade das exportações. O declínio da indústria doméstica contribuiu de forma positiva e significativa para explicar a intensidade das exportações, uma vez que as firmas procuram o mercado externo como forma de contornar o declínio do mercado interno. A propriedade por parte de funcionários apresentou-se positiva e significativa para explicar a probabilidade de exportar, enquanto que a propriedade por estrangeiros apresentou-se negativa para explicar a probabilidade e não significativa para explicar a intensidade das exportações. Parcerias com firmas estrangeiras afetaram negativamente a intensidade das exportações e mostraram-se não significativas para explicar a probabilidade de exportar. $\mathrm{O}$ investimento mostrou-se não significativo para a intensidade e negativo para a probabilidade de exportar. 
Ainda para o estudo de Bishop (2001), a atividade exportadora em período anterior contribuiu positivamente para a probabilidade e intensidade das exportações, enquanto que os custos fixos de entrada no mercado internacional impactaram de forma negativa para explicar a atividade exportadora.

Bernard e Jensen (2001), utilizando informações de firmas americanas no período de 1984 a 1992, investigaram os fatores que influenciam a decisão de exportar. Os autores consideraram as características da firma, os custos de entrada no mercado internacional, spillovers e gastos governamentais de promoção à exportação ${ }^{7}$. As características da firma consideradas foram o tamanho, mensurado pelo número de empregados, e a produtividade, representada pela produtividade total dos fatores. A qualidade da força de trabalho foi representada pelo salário médio e pela proporção de trabalhadores não ligados à produção. Foi considerado também se a empresa é multinacional e se possui mais de uma planta. A taxa de câmbio relativa à indústria representou a resposta dos exportadores a choques de preços.

Os spill-overs foram identificados por variáveis dummy considerando três classificações: spill-overs de região, spill-overs de indústria e spill-overs locais. Os spill-overs de região foram identificados por atividade exportadora no mesmo estado, mas em indústria diferente. Spill-overs de indústria foram identificados por atividade exportadora na mesma indústria, mas fora do estado da firma. Spill-overs locais foram identificados por atividade exportadora na mesma indústria e estado da firma. Para identificar subsídios às exportações foram incluídos os gastos estatais de promoção às exportações. Os custos de entrada no mercado internacional foram avaliados por meio da permanência no mercado exportador. Os autores explicaram que altos custos de entrada no mercado internacional contribuem para

\footnotetext{
${ }^{7}$ Spill-overs são efeitos de transbordamento que resultam de esforços de firmas ou setores e que são aproveitados por outras firmas ou setores. Por exemplo, quando uma firma se beneficia da tecnologia desenvolvida por outra firma do mesmo setor (ARAUJO, 2005; BARRIOS; GORG; STROBL, 2001). O termo Spill-overs muitas vezes é utilizado como sinônimo de externalidades.
} 
maior permanência neste mercado, enquanto baixos custos de entrada permitiriam às firmas entrar e sair com mais freqüência. Para representar estes custos, foi verificado se a firma exportou nos dois anos anteriores, a fim de averiguar se exportações em anos anteriores impactam na decisão atual de exportar.

Os resultados indicaram que a experiência no mercado exportador em anos anteriores contribui de forma positiva e significativa para explicar a decisão de exportar no período atual. Desta forma, os custos de entrada no mercado internacional apresentaram-se negativos e significativos para explicar a decisão de exportar para as empresas americanas. Spill-overs locais, de região e de indústria não foram significativos para explicar a probabilidade de uma empresa exportar. Os gastos governamentais também não apresentaram-se significativos para explicar a probabilidade de uma empresa exportar. As estimativas correspondentes às variáveis tamanho e salários foram positivas e significativas para explicar a probabilidade de exportar. Quanto à propriedade, foi identificado um efeito positivo e significativo para firmas multinacionais, mas, para firmas com mais de uma planta, este efeito não apresentou-se significativo para explicar a probabilidade de exportar. A taxa de câmbio da indústria mostrou sinal negativo sugerindo que uma apreciação nesta taxa reduz a probabilidade de exportar.

Barrios, Gorg e Strobl (2001) examinaram a importância das atividades de P\&D da firma e de externalidades setoriais sobre a probabilidade de exportar e intensidade exportadora. Foram utilizadas informações de 2000 empresas espanholas para os períodos de 1990, 1994 e 1998. O modelo utilizado pelos autores incluiu variáveis relacionadas a firma e ao setor. Das variáveis da firma, foram incluídas a idade, tamanho e produtividade. Foram considerados também o salário por empregado, a parcela de trabalhadores não ligados à produção, a parcela de trabalhadores técnicos, gastos com P\&D sobre as vendas e uma variável dummy indicando se a firma possui mais de uma planta. 
Com relação às variáveis setoriais, foram analisados os gastos com $\mathrm{P} \& \mathrm{D}$ de empresas domésticas do setor sobre as vendas de empresas domésticas do setor para representar gastos com P\&D doméstico. Os gastos com P\&D de empresas estrangeiras do setor sobre as vendas de empresas estrangeiras do setor representaram os gastos com P\&D estrangeiro. Para representar a importância das exportações domésticas foi avaliada a participação das exportações domésticas do setor sobre a participação das exportações domésticas e, esta divisão, sobre o total das exportações. Da mesma forma, foi avaliada a importância das exportações das firmas estrangeiras sobre o total das exportações. Externalidades de P\&D e de exportação foram identificadas por meio de variáveis dummy.

As empresas nacionais e estrangeiras foram analisadas separadamente, bem como as externalidades geradas por firmas nacionais e estrangeiras. Consoante com o trabalho de Roberts e Tybout (1997), firmas maiores e mais maduras apresentaram-se mais prováveis de exportar. A produtividade exerceu impacto positivo e significativo sobre a probabilidade de exportar. O fato de a empresa possuir mais de uma planta reduziu a probabilidade da empresa exportar. Para as variáveis relacionadas à qualificação da mão-de-obra, como salário, parcela de funcionários não ligados à produção e parcela de funcionários de nível técnico, as mesmas exerceram impacto positivo sobre a probabilidade exportadora, sugerindo que maiores salários, maior participação de funcionários de nível técnico e maior parcela de funcionários não ligados à produção contribuem positivamente para a atividade exportadora.

Quanto às externalidades de $\mathrm{P} \& \mathrm{D}$, os resultados apontaram que as firmas nacionais não são beneficiadas por externalidades geradas por firmas multinacionais, mas as firmas estrangeiras obtêm benefícios de externalidades geradas por firmas multinacionais. Os autores explicaram que, "Isto pode indicar que firmas estrangeiras possuem melhor capacidade absortiva para assimilar e utilizar o conhecimento que verte de atividade de P\&D de outras multinacionais na mesma indústria” (BARRIOS; GORG; STROBL, 2001, p.13). Além disto, 
os gastos com P\&D da firma apresentaram-se positivos e significativos para explicar a probabilidade e intensidade das exportações. Para as estimativas da intensidade exportadora, entretanto, foi identificado efeito positivo de externalidades de P\&D geradas por firmas multinacionais para firmas domésticas e estrangeiras.

Roper e Love (2001) analisaram dados de empresas do Reino Unido e da Alemanha e identificaram diferenças nos determinantes da atividade exportadora dos dois países. Os autores consideraram indicadores relacionados à escala de produção (alta e baixa escala de produção), se a firma possui mais de uma planta, se há atividade de $P \& D$ na firma e o tamanho da firma.

A inovação tecnológica foi representada por um indicador qualitativo, utilizando uma variável dummy que indica se houve alguma inovação, pela intensidade de $\mathrm{P} \& \mathrm{D}$ e de inovação, representadas pela proporção de trabalhadores envolvidos em atividades de P\&D e pelo número de alterações realizadas em produtos, respectivamente, e pelo sucesso da inovação dado pela parcela das vendas derivada de inovações introduzidas. As externalidades de setor foram analisadas por meio do número médio de inovações por funcionário geradas no setor da firma. As externalidades de região foram analisadas pelo número médio de inovações por funcionário geradas na região da firma. Por fim, as externalidades da cadeia de fornecedores foram analisadas pelo número médio de inovações por funcionário geradas pelos fornecedores da firma.

A variável considerada para representar o indicador qualitativo de inovação mostrouse positiva tanto na probabilidade de exportar como na intensidade da exportação, embora para o Reino Unido, o indicador não tenha se mostrado significativo para a intensidade de exportação. A intensidade de $\mathrm{P} \& \mathrm{D}$, considerada como uma medida de escala do input $^{8}$ do

\footnotetext{
${ }^{8}$ Inputs são os recursos de entrada de um processo de transformação, como materiais ou informações. Outputs são as saídas ou os resultados de um processo de transformação.
} 
processo de inovação, exerceu impacto negativo sobre a probabilidade de exportar na Alemanha, mas foi positivo para explicar a intensidade das exportações em ambos os países. A intensidade da inovação, medida do output do processo de inovação, não teve efeito sobre a intensidade de exportação e exerceu impacto negativo para explicar a probabilidade de exportar na Alemanha. O sucesso da inovação, que o autor explicou como sucesso comercial da inovação, apresentou efeito positivo tanto na probabilidade de exportar quanto na intensidade de exportação para os dois países. Os resultados destas variáveis indicam que há diferenças na competitividade entre os países, na qualidade dos produtos oferecidos e na intensidade de $P \& D$, o que justificaria, por exemplo, a intensidade de $P \& D$ apresentar sinal negativo para a probabilidade de exportar na Alemanha e não no Reino Unido.

Os autores relataram ainda que ser parte de uma firma com diversas plantas tem impacto positivo para explicar a probabilidade de ser exportador e intensidade das exportações em ambos os países. Este resultado diverge daquele encontrado por Bernard e Jensen (2001), em que ser uma firma com mais de uma planta não contribuiu de forma significativa na decisão de exportar. Quanto à escala de produção, para as firmas do Reino Unido, as variáveis representando alta e baixa escala de produção apresentaram-se negativas e significativas para explicar a intensidade das exportações. Entretanto, as variáveis não foram significativas para explicar a probabilidade de exportar. Para as firmas alemãs, a variável representando baixa escala de produção apresentou-se positiva e significativa para explicar a intensidade das exportações enquanto a variável alta escala de produção apresentou-se negativa e significativa. Contudo, para explicar a probabilidade de exportar, alta e baixa escala de produção não foram significativas. O parâmetro correspondente à variável tamanho da firma apresentou sinal positivo e significativo para explicar a probabilidade e intensidade das exportações enquanto a variável na forma quadrática apresentou-se negativa e 
significativa para explicar a probabilidade e intensidade das exportações. Para o Reino Unido, os parâmetros da variável tamanho não foram significativos.

Wagner (2002) utilizando informações de firmas alemãs analisou a conhecida relação positiva entre tamanho da firma e desempenho exportador e argumentou que poderiam existir fatores não observáveis que estão positivamente correlacionados com o tamanho da firma e que superestimam o coeficiente correspondente a esta variável. Assim, o autor propôs uma abordagem que possibilita controlar esta heterogeneidade não observada na relação entre tamanho da firma e atividade exportadora.

Nesta abordagem, a variável resposta foi a parcela das vendas exportadas e o tamanho da firma foi dado pelo número de empregados e pelas vendas totais. A intensidade do capital humano foi medida pelo salário médio por funcionário para representar os níveis de produtividade. Uma variável dummy foi utilizada para indicar se a firma é parte de uma empresa com diversas plantas. $\mathrm{Na}$ análise, foram avaliadas indústrias de aço e metal de construção, engenharia mecânica e bens plásticos.

Para a análise que utilizou o número de funcionários para representar o tamanho da firma, os resultados indicaram que quando não houve o controle da heterogeneidade da firma, a relação positiva entre tamanho e atividade exportadora da firma foi mantida. A variável salário médio por funcionário apresentou-se positiva e significativa para explicar a intensidade das exportações. A variável dummy para firmas que possuem mais de uma planta apresentou-se negativa para indústria do aço e engenharia mecânica e positiva para bens plásticos. O tamanho da firma na forma quadrática obteve sinal negativo e foi significativa para explicar a intensidade das exportações. Quando a heterogeneidade da firma foi controlada por um modelo de efeito fixo, a relação positiva entre tamanho e atividade exportadora desapareceu. Nas análises em que o tamanho da firma foi representado pelas vendas totais, os resultados foram semelhantes. Quando não houve o controle da 
heterogeneidade, a variável tamanho da firma apresentou-se positiva e significativa para explicar a intensidade das exportações das três indústrias. Entretanto, quando houve um controle para a heterogeneidade, somente para a indústria de aço o coeficiente da variável tamanho foi positivo e significativo para explicar a intensidade exportadora. Assim, os resultados sugerem que há outros fatores que não são mensurados de forma direta, mas que estão correlacionados com o tamanho da firma e que contribuem para a atividade exportadora, superestimando o coeficiente da variável tamanho.

Dijk (2002), utilizando informações de firmas da Indonésia, analisou o comportamento de empresas exportadoras de acordo com a intensidade tecnológica do setor a que ela pertence. Para tal análise, foi utilizada a classificação da taxonomia de Pavitt. O modelo estimado pelo autor considerou o tamanho da firma, medido pelo número de trabalhadores normalizado pelo número de trabalhadores da indústria, a parcela de trabalhadores qualificados, definido pelo nível de escolaridade, os gastos de P\&D sobre o produto da firma e os gastos com treinamento sobre o produto da firma. Para identificar se a firma apresenta controle de capital estrangeiro e se a organização possui mais de uma planta foram utilizadas variáveis dummy, ou seja, apresentam valor 1 se a firma é controlada por estrangeiros e zero caso contrário, e apresentam valor 1 se a firma possui mais de uma planta e zero em caso contrário. Além disto, foram avaliados a intensidade de capital, os custos unitários do trabalho, a concentração da indústria e a idade da firma.

O autor encontrou uma relação positiva entre o tamanho e a intensidade exportadora da firma. Para incluir a hipótese de que a relação tamanho da firma e atividade exportadora seja não linear, a variável tamanho da empresa foi incluída na forma quadrática. Uma explicação para este fato é que "Embora tamanho seja uma vantagem em exportar, isto pode não se aplicar a firmas muito grandes as quais podem ser mais orientadas para o mercado doméstico" (WAKELIN, 1998, p.833). A qualificação da mão-de-obra mostrou-se positiva e 
significativa na determinação da intensidade exportadora, principalmente para o grupo de firmas dominadas pelos fornecedores (supplier dominated), enquanto para as firmas intensivas em escala (scale intensive), o impacto foi negativo. Para os outros dois grupos da taxonomia de Pavitt, fornecedores especializados (specialized supliers) e firmas de base tecnológica (science based), esta variável não foi significativa para explicar a intensidade das exprtações.

Para Dijk (2002), os gastos com P\&D representaram a variável tecnológica. Para as firmas de base tecnológica o parâmetro da variável apresentou-se sempre negativo para explicar a intensidade das exportações. Isto pode ser explicado, segundo o autor, com base nas teorias de comércio internacional, em que firmas de países em desenvolvimento não seriam competitivas em setores de alta tecnologia. Para os três outros grupos da taxonomia de Pavitt, firmas intensivas em escala, firmas dominadas pelos fornecedores e fornecedores especializados, os resultados alteraram-se de acordo com o modelo utilizado. Os resultados sugeriram que indústrias maduras, que se encontram nas categorias de firmas intensivas em escala e firmas dominadas por fornecedores, beneficiam-se de investimento em P\&D. O coeficiente da variável gastos com treinamento apresentou sinal negativo e foi significativo para explicar a intensidade das exportações apenas para a indústria de bebidas e apresentou-se positivo para a indústria de confecções.

O coeficiente da variável participação estrangeira no capital, representada por variável dummy, apresentou impacto positivo sobre a intensidade exportadora e a variável dummy que representou se a firma possui mais de uma planta apresentou impacto positivo e significativo para explicar a intensidade exportadora para a maioria das indústrias, exceto para indústria de artigos de cerâmica. Para a variável intensidade de capital os resultados foram distintos entre os grupos. Para as firmas intensivas em escala (scale intensive), a intensidade de capital não foi um fator importante, contrariando as expectativas, visto que a mesma poderia estar 
refletindo economia de escala. Para a indústria de móveis, a variável intensidade de capital apresentou-se negativamente correlacionada com as exportações. Em contraste, para os outros grupos da taxonomia, firmas dominadas pelos fornecedores (supplier dominated), fornecedores especializados (specialized supliers) e firmas de base tecnológica (science based), a intensidade de capital afetou positivamente a intensidade das exportações. Os custos unitários do trabalho apresentaram coeficiente negativo e significativo para explicar a intensidade das exportações.

Ainda segundo Dijk (2002), não foi possível obter alguma conclusão para o país a respeito da concentração da indústria, visto que esta variável apresentou resultados distintos entre os setores. Para a idade da firma, os resultados apontaram impacto negativo sobre a intensidade das exportações, resultado contrário ao trabalho de Roberts e Tybout (1997) em que a idade contribui de forma positiva para explicar a atividade exportadora. $\mathrm{O}$ autor esclareceu ainda que a relação entre idade e atividade exportadora da firma pode ser vista de duas formas: por um lado, firmas mais maduras possuem maior experiência com mercado internacional, mas firmas mais jovens utilizam tecnologias mais modernas.

Özçelik e Taymaz (2002) analisaram o papel da tecnologia sobre a intensidade exportadora de empresas turcas. Para a análise, utilizaram informações de atividade de inovação de 4000 firmas no período de 1995 a 1997 coletadas por meio de questionário. Os autores elaboraram um modelo Tobit que considerou como variáveis explicativas tecnológicas inovação de produto, inovação de processo, aquisição de tecnologia por meio de licença e a intensidade de $\mathrm{P} \& \mathrm{D}$, representada pelos gastos com P\&D sobre vendas. O tamanho da firma foi representado pelo número de funcionários. Das variáveis relacionadas à composição da força de trabalho foram avaliados o salário real, a parcela dos trabalhadores administrativos, a participação de trabalhadores técnicos e a parcela de trabalhadores do sexo feminino. Com relação à diferenciação de produtos foram avaliados a produção de mercadorias diferenciadas 
e os gastos com propaganda sobre vendas. Quanto à propriedade, foram avaliadas a participação de capital estrangeiro e capital estatal. Foram considerados também a participação da empresa em um grupo de negócios, a idade da firma, a concentração da indústria, a intensidade de capital e a parcela da produção subcontratada por outra firma.

Os resultados indicaram que a concentração da indústria não foi significativa para explicar a intensidade das exportações na Turquia. O custo dos salários também não se mostrou significativo para explicar a intensidade das exportações. Neste caso, acredita-se que os custos do trabalho não constituem uma vantagem para as empresas analisadas. Para os trabalhadores administrativos e técnicos, a contribuição foi negativa e a parcela de trabalhadores do sexo feminino obteve impacto positivo. O impacto da variável inovação de processo foi positivo e significativo sobre a intensidade das exportações, enquanto que a variável inovação de produto não foi significativa. No entanto, quando inovação de processo foi retirada do modelo, inovação de produto passou a ser significativa para explicar a intensidade das exportações. A obtenção de tecnologia por meio de licença não mostrou-se significativa para explicar a intensidade exportadora.

Quanto à diferenciação de produto, a variável não apresentou-se significativa, enquanto os gastos com propaganda obtiveram impacto negativo sobre a intensidade das exportações para as empresas analisadas. As despesas com propaganda, segundo os autores, podem estar direcionadas ao mercado interno, o que tornaria seu impacto negativo para as exportações. Para empresas que têm sua produção subcontratada por outra firma, a relação com a atividade exportadora foi negativa. Os autores argumentaram que uma empresa que vende sua produção a outra como parte de um processo, é menos provável de exportar. Quando uma empresa é membro de um grupo de negócios, a variável não foi significativa para explicar a intensidade exportadora, o mesmo ocorrendo com a idade da firma. 
Liu e Shu (2003) investigaram a relação entre atividade exportadora de empresas chinesas e características da indústria. O trabalho utilizou informações de firmas industriais da China para o ano de 1995, classificadas em setores de alto e baixo grau tecnológico. No modelo considerado, a intensidade exportadora foi representada pelo valor exportado sobre o produto total da respectiva indústria e foram utilizadas quatro variáveis explicativas: investimento estrangeiro direto, tamanho da firma, representado pelo produto total da indústria sobre o número de firmas da indústria; custos do trabalho, representados pelo total dos salários dividido pelo número de funcionários e gastos em P\&D sobre o produto total da respectiva indústria.

Os resultados sugeriram que os custos de trabalho representam um dos mais importantes fatores na determinação da atividade exportadora de empresas chinesas sendo seu parâmetro negativo e significativo para explicar a intensidade exportadora. A intensidade do trabalho impactou de forma positiva e significativa na intensidade exportadora. Entretanto, quando as empresas foram analisadas em grupos de alta e baixa tecnologia, para as firmas de alta tecnologia, os custos e a intensidade do trabalho não foram significativos, enquanto para as firmas de baixa tecnologia, os custos apresentaram sinal negativo e a intensidade do trabalho apresentou sinal positivo, sendo ambos significativos para explicar a intensidade exportadora. Isto pode ser explicado, segundo os autores, devido à abundância do fator trabalho na China e pela competitividade deste país, no mercado internacional, em produtos de baixos custos de trabalho.

O Investimento Estrangeiro Direto (IED) obteve impacto positivo e significativo sobre a intensidade das exportações, independente do grau tecnológico do setor. Os autores esclareceram que:

\footnotetext{
"Isto pode ser porque IED não representa somente fluxo de capital físico para o país anfitrião, mas também constitui um pacote de habilidades administrativas, melhor conhecimento de marketing internacional, e um canal de distribuição bem estabelecido no mercado mundial" (LIU; SHU, 2003, p.52).
} 
A variável tamanho da firma contribuiu de forma positiva e significativa para explicar a intensidade das exportações para setores de alto e baixo grau tecnológico. Quanto aos gastos com $\mathrm{P} \& \mathrm{D}$, os resultados indicaram que a variável não é significativa para explicar a intensidade das exportações. Para firmas de baixo grau tecnológico, a variável P\&D apresentou-se negativa quando a intensidade do trabalho foi considerada no modelo. Isto pode ser justificado pelas características dos produtos que a China exporta, os quais são mais intensivos em trabalho.

Alvarez (2003) utilizou uma abordagem um pouco diferente dos demais trabalhos para averiguar os determinantes da atividade exportadora no Chile. $\mathrm{O}$ autor investigou as características de firmas exportadoras permanentes, exportadoras esporádicas e nãoexportadoras. A justificativa para tal análise é que apenas um pequeno número de empresas que entram no mercado externo permanece exportando por longo período de tempo. Por esta razão, faz-se necessário analisar os fatores que contribuem para o sucesso permanente no mercado internacional. O conjunto de dados conta com informações de mais de 5000 firmas por ano, sendo estas com mais de 10 funcionários, para os anos de 1990 a 1996. O autor utilizou um modelo logit multinomial para realizar a análise empírica.

As variáveis específicas da firma consideradas foram a produtividade total dos fatores, obtida por meio de uma função de produção, o nível de habilidade dos funcionários, representado pela parcela de funcionários não ligados à produção e os gastos com aquisição de licenças técnicas estrangeiras, que representa esforço para a inovação. $\mathrm{O}$ autor analisou também a existência de custos irrecuperáveis na entrada de mercados estrangeiros. Para esta análise utilizou-se de duas abordagens para identificá-los: propriedade estrangeira e externalidades de firmas estrangeiras. O autor justificou que a participação de capital estrangeiro pode contribuir com conhecimento sobre mercados internacionais, o que reduziria os custos para entrar no mercado externo. Além disto, as firmas poderiam ser beneficiadas por 
externalidades de conhecimento e tecnologia de multinacionais. Por fim foram incluídas variáveis dummy para os setores, a fim de incorporar choques setoriais.

Os resultados indicaram que a produtividade total dos fatores tem impacto positivo e significativo sobre a probabilidade de exportar para os exportadores esporádicos. Entretanto, para os exportadores permanentes, a variável não foi significativa para explicar a atividade exportadora. O resultado sugeriu que um aumento na produtividade contribui para uma empresa tornar-se exportadora. Contudo, não é suficiente para que ela se mantenha permanentemente no mercado externo. A qualificação da força de trabalho impactou de forma positiva e significativa sobre a atividade exportadora. Os gastos com obtenção de licenças estrangeiras apresentaram impacto positivo e, segundo o autor, “[...] esta variável estaria capturando futuras reduções de custos que explicam porque algumas firmas são capazes de permanecer exportadoras" (ALVAREZ, 2003, p.17). A participação de capital estrangeiro contribuiu positivamente para explicar a probabilidade de exportar permanentemente, porém, não houve evidências de externalidades de empresas multinacionais. Assim, o autor concluiu que o capital estrangeiro poderia facilitar o acesso de firmas nacionais ao mercado externo, reduzindo os custos irrecuperáveis presentes no início das exportações. As externalidades geradas por firmas multinacionais, contudo, não contribuíram para a atividade exportadora.

Gumede (2004) utilizou um conjunto de 941 firmas para investigar o comportamento exportador de pequenas e médias empresas na África do Sul. O trabalho avaliou se pequenas e médias empresas envolvidas em associações entram no mercado externo com mais facilidade, uma vez que estas associações facilitam os fluxos de informação. Sobre os custos que dificultam a entrada no mercado internacional, o autor argumentou que "[...] empresas enfrentam, entre outros fatores, custos irreversíveis (incluindo custos de embalagem, melhoria na qualidade do produto, estabelecimento de canais com o mercado exportador e acúmulo de 
informações sobre fontes de demanda)" (GUMEDE, 2004, p.379). Assim, empresas envolvidas em associações que possuem intermediários, estariam em melhores condições de entrar e sair do mercado internacional. Além disto, na existência de gastos adicionais para entrada no mercado externo, o fato de uma empresa já ser exportadora influenciaria sua situação futura. Estes custos poderiam interferir também na saída de uma empresa do mercado internacional, uma vez que a firma incorrerá em custos para voltar a este mercado.

O autor utilizou análise de correlação e regressão para avaliar os fatores que influenciam a probabilidade e a intensidade das exportações. A análise de correlação contemplou fatores como restrição às exportações por taxa de juros, falta de financiamento às exportações, competição, taxa de câmbio e políticas governamentais. A regressão logística avaliou a probabilidade e intensidade das exportações e considerou o tamanho da firma, a idade, restrições por competição no país, restrições por acesso a financiamento, impostos, associações e acesso a informações.

A análise de correlação apontou que associações externas e nacionais elevam a probabilidade de da firma exportar, assim como boas perspectivas de lucro para a indústria no próximo ano. As variáveis que representaram incerteza em políticas governamentais e altas taxas de juros apresentaram sinal negativo para explicar a probabilidade de exportar. As restrições por competição e impostos também mostraram-se negativas para explicar a probabilidade de exportar. Para a intensidade das exportações, poucos fatores foram significativos. Associações internas apresentaram impacto negativo sobre a intensidade das exportações, porém associações externas obtiveram parâmetro positivo. Os custos de entrada no mercado internacional apresentaram sinal negativo e o acesso à informação obteve impacto positivo sobre a intensidade das exportações.

A regressão logística para avaliar a probabilidade de exportar indicou que idade, acesso à informação e participação em associações contribuem de forma positiva para 
explicar a probabilidade de uma firma exportar. Para firmas muito pequenas, as restrições por competição e impostos reduziram a probabilidade de uma firma exportar. Os resultados das estimativas para a intensidade das exportações sugeriram que os custos de entrada no mercado internacional, as restrições por taxa de câmbio instável e por acesso a financiamento impactam de forma negativa para explicar a intensidade das exportações.

Yang, Chen e Chuang (2004) analisaram o papel da tecnologia na decisão de exportar de pequenas e médias firmas de Taiwan. Os dados utilizados no estudo correspondem ao ano de 1996 e contém informações de 7794 firmas, das quais 6849 são pequenas (menos de 200 funcionários) e 485 são firmas de porte médio (menos de 400 funcionários). Foi utilizado um modelo Probit para analisar a probabilidade de uma firma exportar. As variáveis tecnológicas foram representadas pelos gastos com $\mathrm{P} \& \mathrm{D}$, compra de tecnologia externa e gastos com treinamento. Para representar as características da firma foram avaliados o tamanho da firma, representado pelo número de funcionários, e a variável tamanho da firma ao quadrado foi incluída para averiguar possível não linearidade. Foram incluídos também intensidade de capital, medida pelo logaritmo do capital físico sobre o número de funcionários, o nível de habilidade da força de trabalho, representado pelo salário de funcionários qualificados (não ligados à produção) sobre custo total dos salários. A produtividade do trabalho foi representada pelo valor adicionado sobre o número de funcionários e os gastos com propaganda foram representados pelos gastos com propaganda sobre vendas. A parcela de vendas subcontratada por outra firma foi considerada para averiguar se a firma atua como subcontratada de uma outra empresa. Para representar o ambiente em que as firmas operam foram incluídas as vendas da indústria, para representar o tamanho do mercado doméstico, e a intensidade de P\&D do setor, para representar a oportunidade tecnológica disponível no setor.

Os resultados indicaram que o tamanho da firma exerce impacto positivo e não linear para explicar a probabilidade da firma exportar. A produtividade do trabalho exerce um 
impacto positivo e significativo sobre a probabilidade de exportar e a variável intensidade de capital não foi significativa para explicar a atividade exportadora. A qualificação do trabalho apresentou-se positiva e significativa para explicar a probabilidade da firma exportar. Todas as variáveis tecnológicas, gastos com $\mathrm{P} \& \mathrm{D}$, compra de tecnologia externa e gastos com treinamento, apresentaram impacto positivo e significativo para explicar as exportações das firmas. Os autores também encontraram impacto negativo dos gastos com propaganda sobre a probabilidade de exportar, resultado semelhante ao encontrado por Özçelik e Taymaz (2002) para as empresas da Turquia. O argumento para tal fato é que:

[...] o processo de gastar em propaganda é benéfico para construir marcas ou comercializar nomes. Uma possível explicação para este resultado poderia ser que exportadores dos NICs (newly - industrialized countries) como Taiwan normalmente atuam como subcontratados de grupos multinacionais [...]. (YANG; CHEN; CHUANG, 2004, p.359).

A variável relacionada ao tamanho do mercado da respectiva indústria apresentou sinal negativo, indicando que um grande mercado doméstico reduz a probabilidade de exportar. O nível tecnológico disponível no setor obteve sinal positivo e significativo e a parcela de vendas subcontratada por outra firma obteve sinal negativo e significativo para explicar a probabilidade de exportar.

Os autores classificaram as firmas por porte para averiguar possíveis diferenças no impacto das variáveis, sendo as classes definidas pelo número de funcionários: firmas com menos de 100 funcionários e firmas com 100 ou mais funcionários. Esta classificação revelou que, para as variáveis tecnológicas, apenas $\mathrm{P} \& \mathrm{D}$ mostrou-se positiva e significativa para as duas classes. Os gastos com treinamento e aquisição de tecnologia foram positivos e significativos para explicar a atividade exportadoras de firmas menores, mas não apresentaram-se significativos para explicar a atividade exportadora de firmas maiores. $\mathrm{O}$ tamanho da firma apresentou sinal positivo e foi significativo para explicar a atividade exportadora das duas classes. A produtividade e o nível de qualificação do trabalho apresentaram impacto positivo e significativo para explicar a atividade exportadoras das duas 
classes. A intensidade de capital foi significativa apenas para a classe de firmas maiores, porém com sinal foi negativo. Os gastos com propaganda e a parcela de vendas subcontratada foram significativos apenas para as firmas maiores e ambas variáveis apresentaram sinal negativo. O tamanho do mercado doméstico e a oportunidade tecnológica do setor foram significativos apenas para as firmas menores, porém, o tamanho do mercado doméstico apresentou sinal negativo e a oportunidade do setor apresentou sinal positivo para explicar a atividade exportadora.

Sjöholm e Takii (2008) estudaram a relação entre redes de relacionamento estrangeiras e as exportações para empresas da Indonésia. Os autores argumentaram que redes de relacionamento contribuiriam para a redução de custos de exportação das firmas, o que as tornariam mais prováveis de exportar. Estas redes de relacionamento foram representadas por propriedade estrangeira e importação de produtos intermediários. O trabalho contou com um conjunto de dados de 26.987 firmas que possuem mais de 20 funcionários para o período de 1990 a 2000. Foram consideradas na análise a produtividade do trabalho, intensidade de capital, o nível de qualificação dos funcionários e o tamanho da firma. Quanto à propriedade da firma foi avaliado se ela é de propriedade pública e se é de propriedade estrangeira. Quanto às relações com o mercado internacional, foi analisado se a firma exportou nos dois anos anteriores e se a firma realizava importação de produtos intermediários

Os resultados revelaram que o tamanho da firma contribui de forma positiva e significativa sobre a atividade exportadora. As estimativas sobre a composição da força de trabalho, contudo, não apresentou resultados conclusivos. Os custos fixos de entrada no mercado internacional exerceram papel negativo sobre as exportações, o que foi identificado por meio do sinal positivo e significativo das exportações no ano anterior. A produtividade do trabalho exerceu impacto positivo e significativo para explicar a probabilidade de exportar. Para a variável de importação, também não foi possível encontrar resultados conclusivos. 
Quanto à propriedade, participação estrangeira no capital apresentou sinal positivo e significativo, enquanto que, propriedade pública não foi significativa para explicar probabilidade de exportar. A intensidade de capital impactou de forma positiva e significativa na intensidade exportadora. Desta forma, das redes de relacionamentos que possivelmente contribuiriam para explicar a atividade exportadora, apenas a participação estrangeira no capital mostrou-se positiva e significativa.

O presente capítulo apresentou uma revisão de literatura de estudos internacionais sobre os determinantes da atividade exportadora. O próximo capítulo apresentará a revisão de literatura dos estudos brasileiros. 


\section{DETERMinANTES DA ATIVIDADE EXPORTADORA}

\section{BRASILEIRA}

A década de 90 foi um período de profundas transformações na economia brasileira. $\mathrm{O}$ processo de liberalização comercial foi uma das mais importantes mudanças ocorridas e provocou uma reestruturação na indústria do país. A partir de 1995 ocorreu a reversão dos superávits comerciais, além de alterações no mercado de trabalho e na competitividade das empresas. A indústria encontrou dificuldades para inserir-se internacionalmente em virtude de suas características que se distanciavam da tendência mundial, em que a competitividade da indústria baseava-se principalmente em inovação e diferenciação de produtos. Diferente do padrão mundial, as exportações brasileiras eram caracterizadas por baixo grau tecnológico e 
se concentravam em commodities $^{9}$ intensivas em recursos naturais e mão-de-obra (DE NEGRI; SALERNO, 2005).

A partir deste cenário, a análise de dados microeconômicos para identificação de fatores que influenciam as exportações fornece subsídios necessários para a formulação de políticas públicas de promoção ao comércio exterior. Entretanto, os trabalhos nesta área são relativamente recentes, em virtude da dificuldade de obter tais dados, que normalmente são sigilosos (ARAUJO, 2005). São relatados a seguir alguns trabalhos que oferecem contribuição aos determinantes da atividade exportadora brasileira.

Pinheiro e Moreira (2000) analisaram as principais características de empresas que exportam bens manufaturados. Em seu estudo, os autores fizeram um panorama desde a liberalização comercial, no início dos anos 90 até o fim da década de 90 . Uma análise das características das empresas e setores apontou que grande parte dos exportadores de manufaturados estava concentrada em setores com salários mais altos que na indústria como um todo e possuíam mão-de-obra comparativamente qualificada. Além disto, o destino mais comum das exportações brasileiras era a América Latina, embora o valor médio exportado por empresa para a América Latina fosse menor que o valor exportado para outras regiões.

Para a análise empírica foi estimado um modelo probit em que a probabilidade de uma empresa exportar foi explicada por suas características individuais e pelo setor a que pertence. O conjunto de dados utilizado é referente aos anos de 1995 a 1997 e o número de empresas variou de 18,4 mil em 1997 a 22,8 mil em 1995. Os resultados indicaram que o tamanho da empresa é o principal fator de influência na probabilidade de uma empresa ser exportadora. A participação estrangeira no capital contribuiu de forma positiva e significativa para explicar a atividade exportadora. Quanto à qualificação do trabalho, a participação de trabalhadores não

\footnotetext{
${ }^{9} \mathrm{O}$ termo commodity é utilizado para referenciar produtos em estado bruto ou com pouca industrialização e que tenha qualidade uniforme. Por exemplo, café, soja, ouro, petróleo, etc.
} 
qualificados apresentou impacto positivo e significativo para explicar a probabilidade de exportar. Em um modelo alternativo, a proporção do trabalho qualificado apresentou impacto negativo sobre a probabilidade de exportar. Os autores justificaram que o Brasil possui vantagem comparativa nos produtos exportados por setores que possuem baixa proporção de mão-de-obra qualificada.

No estudo, Pinheiro e Moreira (2000) sugeriram que para aumentar o volume total de exportações no Brasil, uma política de promoção às exportações deveria estimular o aumento do valor exportado das empresas que já exportam. Além disto, os resultados indicaram que caso a base exportadora fosse expandida, as novas empresas exportadoras tenderiam a ser pequenas e médias empresas.

Arbache (2002) analisou a competitividade internacional das firmas brasileira no que diz respeito aos setores e características das firmas. O autor esclareceu que alguns dos principais obstáculos à competitividade dos produtos brasileiros são os problemas logísticos, carga tributária e falta de incentivos às exportações pelo setor público. Uma comparação entre firmas exportadoras e não exportadoras indicou que firmas exportadoras possuem mão-deobra mais qualificada que firmas não exportadoras. Quanto à remuneração do trabalho, os trabalhadores de firmas exportadoras recebem salários maiores que aqueles recebidos por trabalhadores de firmas não exportadoras, sugerindo que a produtividade de firmas exportadoras seja superior. As firmas exportadoras apresentaram-se maiores que as firmas não exportadoras. $\mathrm{O}$ autor argumentou ainda que "Baseado no usual princípio da complementaridade entre capital e trabalho qualificado, o maior capital humano pressupõe que o nível tecnológico das firmas exportadoras seja maior que o das não exportadoras" (ARBACHE, 2002, p.13).

Os resultados do trabalho sugerem que o tamanho da empresa e a escolaridade dos trabalhadores são as variáveis que provocam o maior impacto na competitividade 
internacional da firma. Além disto, a indústria da qual a firma faz parte parece exercer pouca ou nenhuma influência no desempenho exportador.

Carneiro (2002) estudou o comportamento de firmas exportadoras investigando se empresas com origem de capital nos Estados Unidos e Canadá têm fácil penetração de produtos no exterior em virtude dos canais de comercialização estabelecidos entre matriz e subsidiária. O trabalho contou com um conjunto inicial de dados das 1000 maiores firmas exportadoras no ano 2000, fornecido pela Secretaria de Comércio Exterior (SECEX). Uma análise inicial das firmas apontou que $61 \%$ das empresas exportadoras apresentavam capital nacional e o valor médio exportado por estas empresas nacionais era menor que o valor exportador por empresas de capital estrangeiro. Além disto, as quatro principais atividades exportadoras encontradas na amostra foram alimentos e bebidas, metalurgia, veículos e minerais metálicos, os quais somavam $58 \%$ das exportações.

O autor especificou um modelo econométrico visando mensurar efeitos das variáveis explicativas sobre a taxa de crescimento das exportações das firmas e investigar se há maior propensão de uma firma exportar para o país de origem de seu capital. Dentre os fatores analisados, o tamanho da firma apresentou impacto positivo e significativo para explicar a taxa de crescimento das exportações. As importações impactaram de forma negativa e significativa para explicar a taxa de crescimento das exportações. Quanto às empresas com capital estrangeiro dos EUA e Canadá, os resultados indicaram que estas empresas utilizam seus canais de exportação para os respectivos países de origem.

De Negri (2004) avaliou a importância da origem do capital como determinante das exportações das firmas da indústria brasileira no período de 1996 a 2000. Consoante com o trabalho de Carneiro (2002), a autora observou que das exportações industriais brasileiras no ano 2000, mais da metade correspondia aos setores de alimentos e bebidas, metalurgia básica, automotivo, extração de minerais metálicos e fabricação de outros equipamentos de 
transporte. Dentre as montadoras do setor automotivo, as empresas estrangeiras representam a maioria. Outro ponto importante é que as empresas de capital estrangeiro eram mais envolvidas no comércio internacional, considerando que $84 \%$ das firmas com capital estrangeiro eram exportadoras e $91 \%$ das firmas eram importadoras. Desta forma, grande parte das empresas estrangeiras era importadora e exportadora.

A autora observou que empresas transnacionais possuem maior grau de abertura comercial. Entretanto, ela expôs que "A maior abertura comercial das empresas estrangeiras se dá de forma assimétrica, ou seja, a diferença existente a favor das transnacionais é maior nas importações do que nas exportações [...]" (DE NEGRI, 2004, p.68). Os resultados do trabalho indicaram ainda que empresas estrangeiras não contribuem para a melhoria do saldo comercial brasileiro.

De Negri e Freitas (2004) investigaram se a inovação tecnológica é um determinante das exportações brasileiras. Os autores utilizaram escolaridade média como proxy ${ }^{10}$ para inovação e argumentaram que a escolaridade poderia estar relacionada à capacidade de inovação. No trabalho, foram utilizados indicadores de eficiência de escala obtidos pelo Data Envelopment Analysis (DEA). Estes indicadores de eficiência apontaram que firmas exportadoras são mais eficientes e sua mão-de-obra possui maior escolaridade que as firmas não exportadoras. Além disto, as firmas exportadoras possuem um coeficiente de eficiência de escala $73 \%$ maior que as firmas não exportadoras.

Para identificar se as variáveis tecnológicas e de eficiência de escala impactam na probabilidade de uma firma exportar foi estimado um modelo probabilístico. Tanto a variável de inovação quanto a variável de eficiência de escala foram significativas e positivas para explicar a probabilidade de exportar. Os autores avaliaram se um aumento na eficiência de

\footnotetext{
${ }^{10}$ Variável Proxy é uma forma indireta de medir a variável pretendida. Pode ser utilizada quando o objeto de estudo é difícil de ser medido.
} 
escala e inovação das firmas exportadoras e não exportadoras resultaria em aumento nas exportações. O modelo estimado indicou que $81,6 \%$ no aumento das exportações resultariam das firmas que não exportam e que passariam a exportar. Apoiados nestes resultados, os autores expuseram que "[...] existe uma franja de firmas com potencial para estar inserida no comércio internacional desde que superados problemas competitivos internos à firma e que afetam a sua competitividade no mercado externo como eficiência de escala e propensão a inovar" (DE NEGRI; FREITAS, 2004, p.17). Este resultado diverge dos resultados de Pinheiro e Moreira (2000), os quais sugeriram que para elevar as exportações brasileiras seria mais adequado aumentar o nível das exportações de empresas que já exportam.

De Negri (2005) analisou o papel da inovação tecnológica para explicar a probabilidade de uma firma exportar, volume e intensidade tecnológica das exportações. A autora estimou um modelo utilizando variáveis de eficiência de escala e eficiência técnica, inovação, nacionalidade do capital e uma variável dummy para indicar importação. As variáveis de eficiência de escala e eficiência técnica contribuíram de forma positiva e significativa para explicar a probabilidade da firma exportar, porém a eficiência de escala indicou maior importância. Todas as variáveis que representaram inovação mostraram impacto positivo e significativo para explicar a probabilidade de exportar, porém a inovação de produto para o mercado doméstico foi a variável de maior impacto, dando à empresa uma probabilidade $17 \%$ maior de exportar que as firmas que não inovam.

A origem do capital apresentou impacto positivo e significativo para explicar a probabilidade de exportar. Segundo a autora, empresas com capital estrangeiro possuem probabilidade $30 \%$ maior de exportar do que as empresas nacionais. Além disto, empresas que importam também são mais prováveis de exportar.

Para as estimativas da intensidade das exportações, foram apresentadas seis subdivisões: valor das exportações totais, alta intensidade tecnológica, média intensidade, 
baixa intensidade, produtos intensivos em mão-de-obra e recursos naturais e commodities primárias $^{11}$. A partir desta divisão, tornou-se possível identificar a influência dos diferentes tipos de inovação de acordo com a intensidade tecnológica do produto vendido. Os resultados indicaram que para as commodities primárias, nenhuma das variáveis de inovação foi significativa para explicar a intensidade exportadora, ou seja, a inovação não contribui para as exportações destas firmas. Para as firmas intensivas em trabalho e recursos naturais e as firmas de baixa intensidade tecnológica, as inovações de produto não foram significativas, mas as inovações de processo impactaram de forma positiva e significativa para explicar a intensidade das exportações. Para as firmas de média intensidade tecnológica, as variáveis de inovação de produto e inovação de processo apresentaram coeficientes positivos e significativos para explicar a intensidade das exportações. Por fim, para as firmas de alta intensidade tecnológica, a inovação de produto não foi significativa para explicar a intensidade das exportações, apenas inovação de processo. A autora explica que:

Talvez a inovação de produto para o mercado, por parte dessas firmas, seja apenas uma adaptação, ao mercado doméstico, de produtos já conhecidos e comercializados no mercado internacional. Assim, como a inovação de produto é dirigida para o mercado doméstico, seus impactos sobre o desempenho externo da firma não seriam significativos. (DE NEGRI, 2005, p. 16).

A respeito do capital estrangeiro, os resultados indicaram que empresas com participação estrangeira no capital são mais prováveis de exportar. Este impacto positivo se manteve em praticamente todas as divisões, com exceção de commodities primárias.

Araujo (2005) fez uma revisão de literatura sobre os determinantes das exportações. O trabalho apresentou algumas teorias de comércio internacional e relatou as conclusões obtidas por outros autores. Foram apresentados conceitos como custos fixos de entrada no mercado internacional e relações de causalidade entre produtividade e atividade exportadora. $\mathrm{O}$ trabalho relatou aspectos importantes tanto para países em desenvolvimento quanto países

\footnotetext{
${ }^{11}$ A análise da intensidade das exportações têm como variável dependente a parcela das vendas que é exportada.
} 
desenvolvidos como produtividade, tamanho da firma, transnacionalidade e determinantes tecnológicos. Os estudos empíricos revisados pelo autor revelaram que custos de entrada no mercado internacional afetam negativamente as exportações. A respeito das empresas brasileiras, a revisão de literatura realizada pelo autor indicou que as firmas exportadoras são mais produtivas que as firmas não exportadoras, que existe uma relação positiva entre tamanho da firma e probabilidade/valor exportado e que a inovação de produto e processo afeta positivamente a probabilidade de uma firma exportar.

Araujo e Pianto (2006), utilizando informações de 22.193 firmas brasileiras, analisaram o potencial exportador destas firmas. No estudo foi utilizada a técnica Propensity Score Matching (PSM) para classificar firmas de acordo com o potencial exportador. Os autores classificaram as empresas em quatro classes: firmas voltadas para o mercado interno (nível 1), firmas potenciais exportadoras (nível 2), firmas exportadoras gêmeas (nível 3) e firmas exportadoras singulares (nível 4). As firmas potenciais exportadoras (2) são firmas que não exportam, mas possuem características semelhantes às firmas exportadoras gêmeas (3). A análise das firmas apontou que as firmas não exportadoras menos eficientes (nível 1) contam com mão-de-obra de menor escolaridade e inovam menos. Os resultados da técnica utilizada indicaram que produtividade, tamanho e transnacionalidade estão positivamente relacionados às exportações no ano 2000 .

Os autores mencionaram ainda que as firmas potenciais exportadoras (nível 2) apresentam características semelhantes a empresas exportadoras gêmeas (nível 3), porém, mesmo em condições similares, não são capazes de exportar. Para explicar esta dificuldade em exportar, foram apontados como obstáculos às exportações a inércia e os custos de entrada no mercado internacional. Há, entretanto, um ponto que contrasta com o trabalho de Pinheiro e Moreira (2000). Segundo Pinheiro e Moreira (2000), para aumentar o valor das exportações 
deve-se aumentar o valor exportado das firmas já exportadoras, enquanto o trabalho de Araújo e Pianto concluiu que:

\begin{abstract}
A ampliação da base exportadora, além de trazer muitos benefícios ao parque industrial, pode constituir uma alternativa viável também do ponto de vista do volume exportado, ainda mais se for considerado que as exportadoras singulares, por terem uma dinâmica própria, podem ser insensíveis às políticas de promoção das exportações. (ARAUJO; PIANTO, 2006, p. 26).
\end{abstract}

As conclusões de Araujo e Pianto (2006) são semelhantes às conclusões de De Negri e Freitas (2004), os quais defendem a ampliação da base exportadora como forma de elevar as exportações.

Kannebley e Valeri (2006) investigaram a hipótese de histerese (hysteresis) para as exportações industriais brasileiras e os determinantes de permanência de empresas no mercado externo ${ }^{12}$. Os autores avaliaram se as condições inicias da empresa ao entrar no mercado exportador e a inovação contribuem para sua maior permanência neste mercado. Para a análise foi utilizado um conjunto de dados de 10.597 firmas de 1997 a 2003, provenientes da Secretaria de Comércio Exterior (Secex), da Pesquisa Industrial Anual (PIA) e da Relação Anual de Informações Sociais (Rais).

Os resultados apontaram impacto positivo entre maior permanência da firma no mercado externo e o tamanho da firma. A produtividade do trabalho e o capital estrangeiro também apresentaram uma relação positiva com maior permanência da firma no mercado externo. O salário médio e o nível médio de educação dos trabalhadores apresentaram relação negativa com maior permanência no mercado externo, indicando que maiores salários e maiores níveis de educação reduziriam a permanência no mercado externo. As variáveis dummy de inovação não foram estatisticamente significativas para explicar a permanência no mercado externo. Entretanto, quando se separa as empresas inovadoras das empresas não inovadoras, as não inovadoras possuem maior probabilidade de permanecer no mercado

\footnotetext{
${ }^{12}$ Histerese é definida como um efeito permanente causado por um choque temporário.
} 
externo, em virtude de menores custos de salários, maior escala e maior produtividade do trabalho. Os autores também explicaram que para as empresas não inovadoras as condições anteriores à entrada no mercado externo são mais relevantes para sua maior permanência no mercado externo. Quanto aos custos fixos de entrada no mercado internacional, os resultados sugeriram que eles interferem na decisão de entrada ou saída do mercado externo, tornando mais lenta a decisão de entrar no mercado externo ou sair dele.

Kannebley et al (2009) analisaram as hipóteses de auto-seleção e aprendizado para as exportações brasileiras. A hipótese de auto-seleção das firmas mais produtivas para o mercado externo foi fundamentada na existência de custos de entrada no mercado internacional, como distribuição e adequação de produtos aos padrões internacionais. Estes custos constituem uma barreira de entrada ao mercado externo, a qual empresas mais eficientes teriam maiores possibilidades de superar. A hipótese de aprendizado decorrente da exportação fundamentouse em ganhos de eficiência devido à exposição de melhores práticas gerenciais e tecnológicas, além de níveis mais elevados de competitividade.

Para avaliar estas duas hipóteses, os autores utilizaram dados da Secretaria de Comércio Exterior (Secex), da Pesquisa Industrial Anual (PIA) e da Relação Anual de Informações Sociais (Rais), dos anos de 1997 a 2006 para a indústria de transformação. Uma análise descritiva dos dados mostrou que empresas exportadoras são maiores, possuem funcionários mais qualificados, mensurado pelo tempo médio de estudo, e com remuneração superior às empresas não exportadoras.

Os resultados sugeriram que há uma relação positiva entre valor exportado e tempo de permanência no mercado externo, ou seja, conforme aumenta o tempo que a empresa está exportando, aumenta o valor exportado por ela. Para identificar a presença de histerese nas exportações industriais, Kannebley et al (2009) utilizaram um modelo linear de probabilidade dinâmico. As estimativas indicaram a presença de histerese na atividade exportadora, o que 
foi identificado a partir da existência de custos de entrada e/ou saída do mercado externo. Os resultados sugeriram que estes custos podem causar maior impacto em firmas menores.

Para investigar a relação entre valor de estréia no mercado externo e a probabilidade de permanência na base exportadora Kannebley et al (2009) utilizaram uma regressão multinomial logística. Os autores explicaram que o valor de estréia no mercado exportador pode ser considerado uma boa proxy para o custo de entrada, uma vez que quanto maior o custo, mais a empresa terá que vender para diluí-lo. Os resultados indicaram que o valor de estréia apresenta impacto positivo e significativo para explicar a probabilidade de permanência no mercado externo. Para os prêmios de produtividade e efeito aprendizado, o trabalho indicou que empresas estreantes em 2000 já apresentavam prêmios de produtividade $30 \%$ superiores às empresas não exportadoras, o que aumentou no ano de estréia destas empresas no mercado externo. Após o ingresso, este diferencial de produtividade aumentou e os autores concluíram que houve um efeito de aprendizado para empresas exportadoras.

Hidalgo e Mata (2009) estudaram a produtividade das firmas industriais brasileiras a fim de mensurar as diferenças de produtividade entre firmas exportadoras e não exportadoras da indústria de transformação para o período pós abertura comercial, entre 1997 e 2003 . Com isto, os autores pretendiam identificar a existência de um processo de seleção para as empresas que exportam e verificar se há diferença no crescimento da produtividade das firmas, ou seja, se há um processo de aprendizado. Os autores mencionaram que em virtude de custos irrecuperáveis e maior exposição à competição, empresas mais eficientes seriam mais prováveis de permanecer no mercado externo.

Para comparar a produtividade das firmas, os autores analisaram a distribuição cumulativa da produtividade total dos fatores e da produtividade do trabalho para quatro classes: firmas exportadoras, firmas não exportadoras, firmas exportadoras entrando no mercado externo, ou seja, no primeiro ano da amostra, e firmas exportadoras saindo do 
mercado externo. O teste não-paramétrico de Kolmogorov - Smirnov foi utilizado para identificar diferenças na produtividade das quatro classes. Para realização do trabalho, foram utilizados dados da Pesquisa Industrial Anual (PIA), da Secretaria de Comércio Exterior (SECEX) e da Relação Anual de Informações Sociais (RAIS). Quanto ao porte, as firmas foram divididas entre firmas de pequeno e grande porte. Os resultados apontaram maiores níveis de produtividade para as firmas exportadoras e estas diferenças são maiores para as firmas de pequeno porte. Quando as firmas foram analisadas por porte, aceitou-se a hipótese de seleção para as firmas de pequeno porte, mas não para as firmas de grande porte. Na saída das empresas do mercado externo, as firmas exportadoras também apresentaram maiores níveis de produtividade. Os resultados referentes ao aprendizado não apontaram que o crescimento da produtividade das firmas exportadoras fosse estatisticamente diferente das firmas não exportadoras, não podendo, portanto, afirmar que exista um processo de aprendizado, o que contraria os resultados encontrados por Kannebley et al (2009).

A partir da revisão de literatura apresentada, o próximo capítulo apresenta o modelo e variáveis propostos nesta pesquisa, bem como a amostra e a análise econômica dos resultados. 


\title{
4 AnÁlise dos Determinantes da Atividade
}

\author{
EXPORTADORA PAULista
}

\subsection{INTRODUÇÃO}

Este capítulo tem por objetivo apresentar os modelos utilizados na presente pesquisa, bem como os métodos considerados na avaliação da probabilidade de uma firma exportar. Para verificar o impacto das variáveis explicativas do modelo sobre a probabilidade de uma empresa exportar, utilizou-se os métodos Probit e Logit. As estimativas para os parâmetros dos modelos foram realizadas no software SAS. 
Com o intuito de investigar os efeitos das variáveis explicativas para diferentes grupos de empresas, a amostra foi classificada conforme o grau tecnológico. As empresas foram identificadas como sendo de baixo e alto grau tecnológico.

Os dados utilizados no presente trabalho são oriundos da Pesquisa da Atividade Econômica Paulista (PAEP), realizada em 1996 e em 2001, pela Fundação Sistema Estadual de Análise de Dados (SEADE). Os dados foram coletados por meio de questionários e são restritos a indústrias de São Paulo.

Este capítulo está dividido em 5 seções, incluindo esta introdução. A seção 4.1 apresenta os métodos Probit e Logit. A seção 4.2 contém uma descrição das variáveis utilizadas nos modelos. A seção 4.3 apresenta uma análise descritiva dos dados. Na seção 4.4 apresentam-se as especificações dos modelos bem como o critério de classificação considerado. A seção 4.5 apresenta a análise econômica dos resultados.

\subsection{MÉTODOS}

O objetivo da utilização de uma técnica econométrica neste estudo é identificar os fatores estatisticamente significativos para explicar a atividade exportadora de uma empresa. Deseja-se estimar a probabilidade de uma empresa exportar, sendo, portanto, necessária a utilização de uma técnica adequada em que a variável resposta é caracterizada como binária.

Existem alternativas de modelagem para modelos com variáveis respostas binárias, como: Modelo de Probabilidade Linear, Modelo Probit e Modelo Logit. Neste trabalho serão utilizadas as técnicas Probit e Logit.

Os modelos Probit e Logit são modelos de probabilidade não-lineares capazes de estimar os parâmetros das variáveis que explicam uma determinada probabilidade. Sendo $Y$ a variável dependente, utiliza-se, por exemplo, $Y=1$ para empresas que são exportadoras e $Y=0$ para empresas que não exportam. Para que os valores previstos permaneçam no 
intervalo $(0,1)$, utilizam-se funções de distribuição de probabilidade acumulada (f.d.a $)^{13}$. Mais especificamente, deseja-se estimar o valor médio esperado da variável dependente, dados os valores das variáveis explicativas, representado por:

$$
E\left(Y \mid X_{1}, X_{2}, \ldots, X_{k}\right)=P\left(Y=1 \mid X_{1}, X_{2}, \ldots, X_{k}\right)
$$

Para o modelo Probit, é utilizada a função de distribuição normal acumulada padrão e a relação entre a probabilidade de uma empresa exportar e as variáveis explicativas é demonstrada como a expressão abaixo:

$$
P\left(Y=1 \mid X_{1}, X_{2}, \ldots, X_{k}\right)=\varphi\left(\alpha+\beta_{1} X_{1}+\beta_{2} X_{2}+\ldots+\beta_{k} X_{k}\right)
$$

em que $Y$ é a variável dependente binária, $\varphi$ é a função de distribuição normal acumulada padrão, $\alpha$ é o intercepto e $X_{1}, X_{2}, \ldots, X_{k}$ são as variáveis explicativas. Para calcular a probabilidade de $Y=1$, dadas as variáveis explicativas, utiliza-se o valor de $z$, apresentado abaixo:

$$
z=\alpha+\beta_{1} X_{1}+\beta_{2} X_{2}+\ldots+\beta_{k} X_{k}
$$

A equação (4.3) é utilizada para encontrar a área sob a curva que se encontra à esquerda de $z$ e, assim, encontrar a probabilidade associada a esta área. O cálculo da probabilidade na cauda à esquerda de $z$ é obtido por $P(Z \leq z)$.

A probabilidade de $Y=1$ é calculada da seguinte forma:

$$
P\left(Y=1 \mid X_{1}, X_{2}, \ldots, X_{k}\right)=\varphi(z)
$$

Por se tratarem de modelos probabilísticos, os parâmetros estimados para os modelos Probit e Logit não são interpretados diretamente. Alternativamente, são analisados os sinais dos coeficientes estimados para cada variável explicativa do modelo. Se o parâmetro de uma variável explicativa tiver sinal negativo, significa que um aumento no valor desta variável

\footnotetext{
${ }^{13}$ Função que mostra a probabilidade de uma variável aleatória ser menor ou igual a dado número.
} 
reduz a probabilidade de determinado evento ocorrer. Da mesma forma, se o sinal correspondente ao parâmetro de uma variável explicativa for positivo, significa que um aumento no valor desta variável aumenta a probabilidade da empresa exportar.

Para o modelo Logit, é utilizada a função de distribuição logística acumulada padrão, representada conforme a expressão (4.5):

$$
\begin{aligned}
P\left(Y=1 \mid X_{1}, X_{2}, \ldots, X_{k}\right) & =F\left(\alpha+\beta_{1} X_{1}+\beta_{2} X_{2}+\ldots+\beta_{k} X_{k}\right) \\
& =\frac{1}{1+\exp \left[-\left(\alpha+\beta_{1} X_{1}+\beta_{2} X_{2}+\ldots+\beta_{k} X_{k}\right)\right]}
\end{aligned}
$$

em que $Y$ é a variável dependente binária, $F$ é a função de distribuição logística acumulada padrão, $\alpha$ é o intercepto e $X_{1}, X_{2}, \ldots, X_{k}$ são as variáveis explicativas. De maneira similar ao modelo Probit, no modelo Logit, o $z$ é obtido conforme a expressão (4.3). Conseqüentemente, a expressão (4.5) é escrita da seguinte forma:

$$
P=\frac{1}{1+e^{-z}}
$$

Desta forma, no modelo Logit a probabilidade de $Y=1$ é expressa por (4.6).

Para a estimação dos parâmetros de modelos com variável dependente binária não-linear utiliza-se o método de Máxima Verossimilhança (MV) devido à não-linearidade dos coeficientes. Stock e Watson (2004, p. 211) explicam que "Como a função de regressão da população é uma função não-linear dos coeficientes $\beta_{0}, \beta_{1}$, etc., aqueles coeficientes não podem ser estimados por MQO”.

Na próxima seção são descritas as variáveis explicativas do modelo considerado nesta pesquisa.

\subsection{DESCRIÇÃO DAS VARIÁVEIS}


Para mensurar a probabilidade de uma empresa exportar foram selecionadas medidas de escala de produção, produtividade, capital humano, transnacionalidade, inovação, competitividade passada, estabelecimento de canal de comercialização externo e diferenciação de produto. A taxa de câmbio, embora importante variável macroeconômica e que exerce grande influência no comportamento exportador, não foi considerada nesta análise porque exerce impacto sobre todas as empresas.

Como medida de escala de produção foi utilizado o número de empregados. A medida de escala de produção está associada à redução dos custos de produção. Além disto, o aumento do tamanho da empresa contribui para cobrir os custos irrecuperáveis de entrada no mercado internacional e está associado a melhores condições para obter financiamentos junto a terceiros. A variável tamanho da empresa foi considerada na forma quadrática para identificar possível não linearidade entre o tamanho da empresa e a probabilidade de exportar, ou seja, o tamanho da empresa contribui para que a firma se torne exportadora mas o aumento do tamanho da firma eleva também os custos da empresa. Assim quando o tamanho da firma torna-se muito grande, os custos também se elevam muito, reduzindo a probabilidade de exportar. Desta forma, a relação entre tamanho da empresa e probabilidade de exportar é positiva, mas não é linear.

Para representar a produtividade foi utilizada a produtividade média do trabalho que indica o quanto cada unidade de trabalho produz. A variável foi construída a partir do valor adicionado pela empresa dividido pelo número de empregados. O valor adicionado pela empresa, obtido da base de dados da PAEP, corresponde ao valor bruto da produção menos o consumo intermediário. A variável produtividade é representada conforme a expressão (4.7):

$$
\text { Produtividade }=\frac{\text { Valor Adicionado }}{\text { Número de Empregados }}
$$

A produtividade do trabalho também está associada aos custos do trabalho e, portanto, influencia na lucratividade da firma. Assim, quanto maior a produtividade, maior a 
produção por trabalhador. Como o valor adicionado é dado em valor monetário, a produtividade por empregado também é definida em valor monetário.

Para identificar o papel do capital humano, foi considerada a participação do trabalho qualificado. O trabalho qualificado foi considerado como a proporção dos trabalhadores não ligados à produção e indica o nível de habilidade do capital humano, o que provavelmente estaria relacionado às características e qualidade dos produtos exportados pela empresa ${ }^{14}$. A variável trabalho qualificado é representada conforme a expressão (4.8):

$$
\text { Mão-de-Obra Qualificada }=\frac{\text { Número de empregados não ligados à produção }}{\text { Total de Empregados }}
$$

A participação estrangeira no capital da empresa foi indicada por uma variável dummy. Em virtude da ausência de informações referentes à porcentagem do capital estrangeiro no capital da empresa, foram consideradas como transnacionais tanto as empresas que contenham todo o capital em poder de estrangeiros como as empresas que possuem apenas uma parcela do capital em poder de estrangeiros. Esta variável representa transferência de capital. Além da transferência de capital, a participação de capital estrangeiro no capital da empresa estaria relacionada à transferência de tecnologia e capacidade gerencial bem como maior facilidade de acesso aos canais de comercialização com o exterior, uma vez que as firmas podem comercializar com suas matrizes.

As variáveis de inovação tecnológica consideradas nesta pesquisa foram inovação, departamento específico de pesquisa e desenvolvimento (P\&D) e registro de patentes. Estas variáveis foram consideradas de forma diferente das demais variáveis mencionadas. Cada variável tecnológica foi avaliada separadamente, uma vez que as inovações realizadas e patentes registradas são output do processo de inovação e pesquisa e desenvolvimento (P\&D)

\footnotetext{
${ }^{14}$ Esta forma de representar o nível de habilidade do capital humano foi utilizada por não ser possível obter o nível de escolaridade dos trabalhadores. Uma maneira semelhante foi utilizada nos estudos de Alvarez (2003) e Sjöholm e Takii (2008).
} 
representa input do processo de inovação. Para a variável que representa as inovações realizadas não foram diferenciadas as fontes de informação, sejam clientes, concorrentes, fonte de informação interna, universidades ou qualquer outra fonte. Também não foi diferenciado o tipo de inovação, seja inovação de produto, inovação de processo, inovação para a empresa ou para o mercado. Desta forma, a variável dummy indica apenas se a empresa realizou alguma inovação. A variável inovação tecnológica, ao gerar mudanças técnicas e de produtos, pode representar aumento da competitividade da firma.

A variável pesquisa e desenvolvimento $(P \& D)$ considerou a realização de atividade interna de $\mathrm{P} \& \mathrm{D}$ em um departamento específico e representa construção de conhecimento na geração de mudanças técnicas e de produtos ${ }^{15}$. A variável pesquisa e desenvolvimento foi representada por uma variável dummy. A terceira variável tecnológica considera o registro de patente e também representa competitividade da firma e vantagem sobre seus concorrentes. A variável patente também foi representada por uma variável dummy.

A idade da firma, calculada pela diferença entre o ano da pesquisa e o ano de fundação da empresa, foi inserida no modelo para indicar competitividade passada, uma vez que empresas mais eficientes são mais prováveis de sobreviver.

Para considerar atividade de importação foi utilizada uma variável dummy que apresenta valor igual a 1 se a empresa importou no período atual e 0 se a empresa não importou. O motivo para a inclusão desta variável é que para exportar uma empresa necessita desenvolver um canal de comercialização, obter informações sobre preferências dos consumidores no exterior e possuir estrutura legal adequada. Desta forma, a importação facilitaria o desenvolvimento de canais de comercialização com o exterior.

\footnotetext{
${ }^{15}$ Existem críticas quanto à utilização desta medida para avaliar inovação, uma vez que muitas firmas não possuem departamentos específicos de P\&D, especialmente pequenas e médias empresas (STERLACCHINI, 1999; DIJK, 2002)
} 
Os gastos com propaganda foram representados pelos gastos com propaganda sobre a receita. Esta variável poderia refletir a estratégia de diferenciação utilizada pela firma. Para o mercado externo, esta seria uma forma de a empresa estabelecer comunicação com o mercado consumidor. A variável gastos com propaganda é representada conforme a expressão (4.9):

$$
\text { Gastos com Propaganda }=\frac{\text { Gastos com propaganda }}{\text { Receita }}
$$

O Quadro 1 apresenta as variáveis que são utilizadas na pesquisa, bem como a forma de identificação e a forma de cálculo. Para maiores esclarecimentos foram incluídos no referido quadro o significado de cada variável no modelo.

\begin{tabular}{|c|c|c|c|}
\hline Variável & Sigla & Modo de Calcular & Significado \\
\hline Tamanho & Tam & Número de Empregados & $\begin{array}{l}\text { Economia de escala, tamanho mínimo } \\
\text { para cobrir custos de entrada }\end{array}$ \\
\hline $\begin{array}{l}\text { Produtividade } \\
\text { Média do } \\
\text { Trabalho }\end{array}$ & Prod & $\frac{\text { Valor adicionado }}{\text { Número de Empregados }}$ & Redução de custos, lucratividade \\
\hline $\begin{array}{l}\text { Mão-de-Obra } \\
\text { Qualificada }\end{array}$ & Quali & $\frac{\text { Número de empregados não ligados à produção }}{\text { Total de Empregados }}$ & $\begin{array}{l}\text { Nível de qualificação da mão-de- } \\
\text { obra, qualidade dos produtos }\end{array}$ \\
\hline $\begin{array}{l}\text { Capital } \\
\text { Estrangeiro }\end{array}$ & $\mathrm{CE}$ & $\begin{array}{c}\text { Dummy se há participação estrangeira no } \\
\text { capital }\end{array}$ & $\begin{array}{l}\text { Canais de comercialização, } \\
\text { transferência de conhecimento }\end{array}$ \\
\hline Idade da Firma & Ida & Ano corrente - Ano fundação & Competitividade Passada \\
\hline Importação & $\operatorname{Imp}$ & Dummy se empresa importou no período & Canal de comercialização externo \\
\hline $\begin{array}{l}\text { Gastos com } \\
\text { Propaganda }\end{array}$ & Prop & $\frac{\text { Gastos com propaganda }}{\text { Receita }}$ & Diferenciação de produto \\
\hline Inovação & Inov & $\begin{array}{c}\text { Dummy se empresa realizou inovação no } \\
\text { período }\end{array}$ & Competitividade \\
\hline Patente & Pat & $\begin{array}{c}\text { Dummy se empresa registrou patente no } \\
\text { período }\end{array}$ & $\begin{array}{l}\text { Competitividade, vantagem na } \\
\text { comercialização da inovação }\end{array}$ \\
\hline $\mathrm{P} \& \mathrm{D}$ & PD & Dummy se empresa possui $\mathrm{P} \& \mathrm{D}$ & $\begin{array}{l}\text { Construção de conhecimento para a } \\
\text { geração de inovação }\end{array}$ \\
\hline
\end{tabular}

Quadro 1 - Variáveis utilizadas na elaboração do modelo

O quadro 1 apresentou as variáveis explicativas consideradas neste estudo para explicar a probabilidade de exportar. A variável tamanho da empresa foi utilizada como medida de escala de produção; a produtividade média do trabalho foi utilizada para 
representar produtividade; o nível de qualificação do capital humano foi representado pela variável mão-de-obra qualificada; a participação estrangeira no capital da empresa foi identificada por meio de uma variável dummy; a inovação tecnológica foi representada por três medidas, inovação, registro de patentes e P\&D, todas identificadas por variáveis dummy; a variável idade da firma foi considerada para representar competitividade passada; a importação de produtos foi considerada para representar o estabelecimento de canal de comercialização externo e diferenciação de produtos foi representada pelos gastos com propaganda.

Na próxima seção é apresentada uma análise descritiva dos dados utilizados neste estudo.

\subsection{ANÁliSE DESCRITIVA dos DADOS}

Os dados utilizados no presente trabalho são oriundos da Pesquisa da Atividade Econômica Paulista (PAEP) realizada em 1996 e em 2001 pela Fundação Sistema Estadual de Análise de Dados (SEADE). A amostra utilizada é composta por 9.298 firmas industriais para o ano de 1996, entre elas 1.704 exportadoras e 7.594 firmas não exportadoras. A amostra de 2001 é composta por 9.733 firmas industriais, entre elas 2.252 exportadoras e 7.481 não exportadoras.

O número de empregados foi considerado para classificar as firmas conforme o porte: micro, pequenas, médias e grandes firmas. A Figura 1a apresenta a distribuição das firmas para o ano de 1996 de acordo com o porte e a Figura 1b apresenta a distribuição das firmas para o ano de 2001 . 


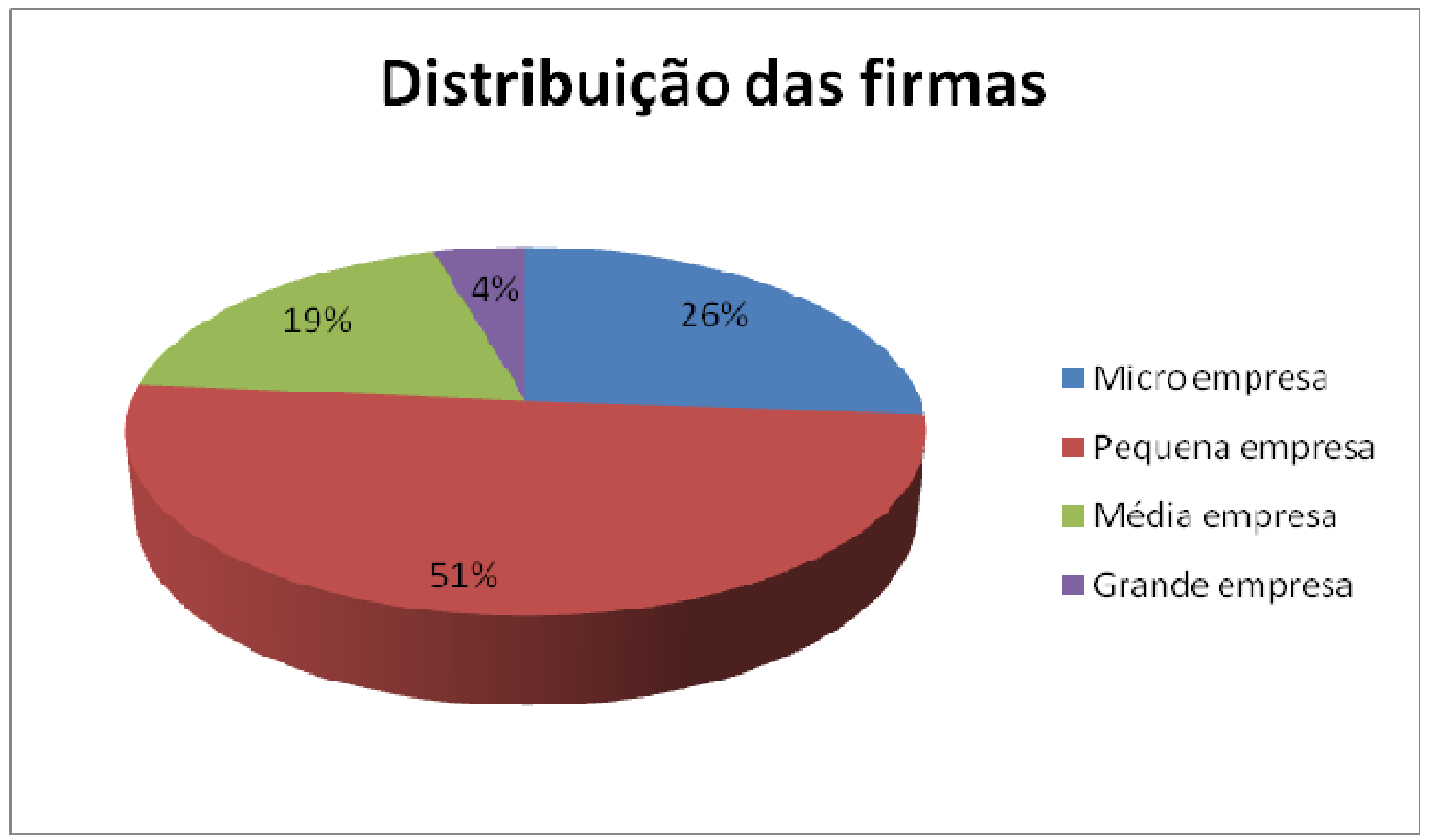

Figura 1a - Distribuição das firmas por porte

Fonte: Elaborada a partir de dados da PAEP 1996

Para o ano de 1996, 26\% das firmas foram classificadas como micro empresas. As pequenas empresas representaram $51 \%$ da amostra, enquanto as firmas de médio porte representaram 19\% da amostra. As firmas de grande porte apresentaram a menor participação, somente $4 \%$ do total das firmas.

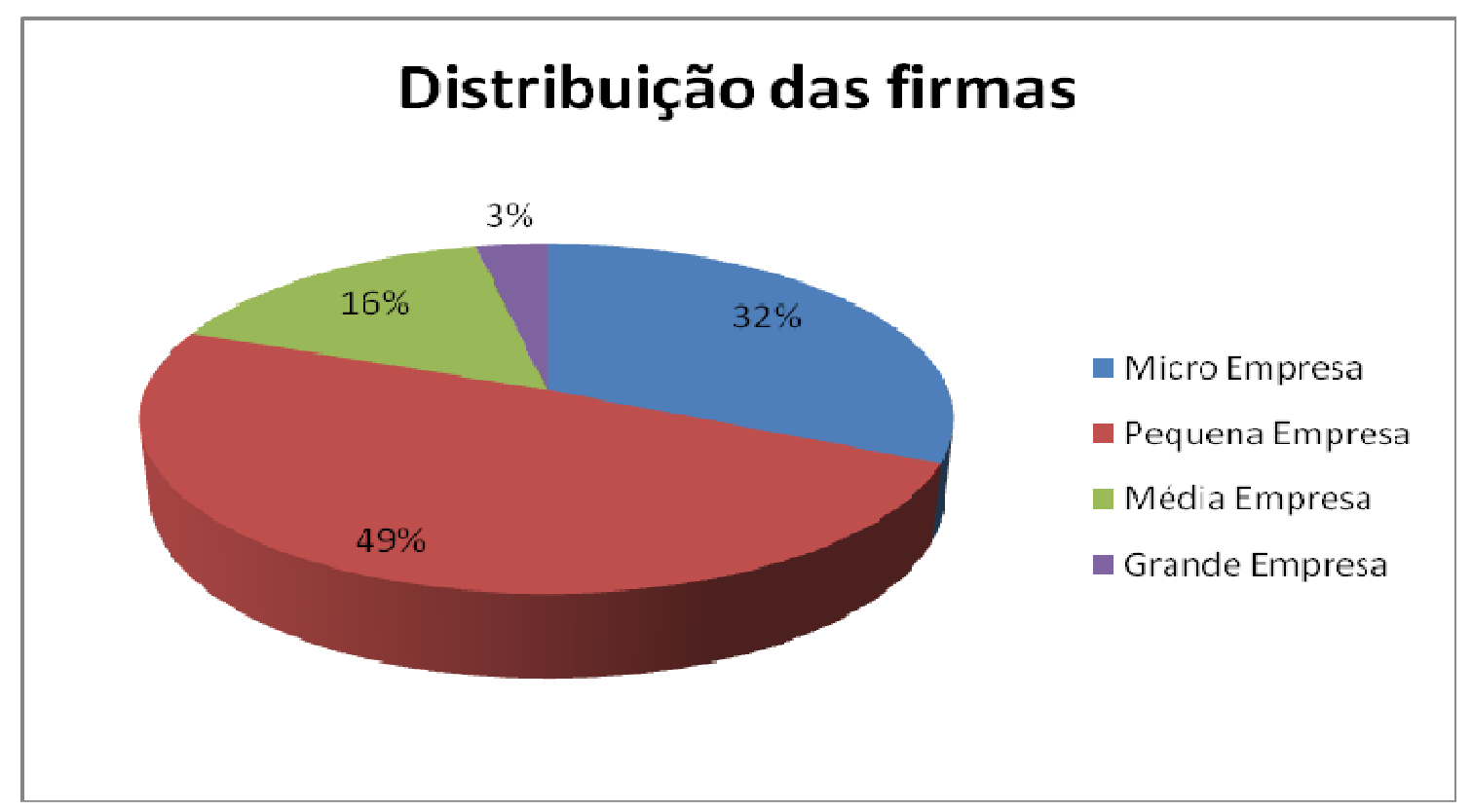

Figura 1b - Distribuição das firmas por porte

Fonte: Elaborada a partir de dados da PAEP 2001 
Para o ano de 2001, a distribuição das firmas foi similar. Houve um pequeno aumento na participação das micro empresas que passaram a representar $32 \%$ da amostra, enquanto que para as firmas de pequeno e médio porte, a participação na amostra foi reduzida para 49\% e $16 \%$, respectivamente. As firmas de grande porte também apresentaram uma redução na participação e representaram 3\% da amostra.

A partir das figuras $1 \mathrm{a}$ e $1 \mathrm{~b}$, percebe-se que as micro e pequenas empresas representaram quase $80 \%$ das firmas e que as pequenas empresas representaram a maioria das firmas. As firmas de médio e grande porte apresentaram menor participação na amostra

A análise descritiva das características das firmas contidas na amostra evidenciou, tanto em 1996 quanto em 2001, que as firmas exportadoras são, em média, maiores, mais produtivas e possuem mais trabalho qualificado quando comparadas com as firmas não exportadoras. Entretanto, quando se analisa estas características por porte, a exceção é o trabalho qualificado. Para as micro, pequenas e médias empresas, o trabalho qualificado possui maior participação nas firmas exportadoras que nas firmas não exportadoras. Contudo, para as grandes empresas, a parcela de trabalho qualificado é menor para as firmas exportadoras, conforme as tabelas A, B, C e D do anexo.

A Tabela 1 apresenta os valores médios para as variáveis tamanho, produtividade e trabalho qualificado para as empresas exportadoras e não exportadoras, divididas em inovadoras e não inovadoras, nos anos de 1996 e 2001. São apresentados também o número de patentes registradas, o número de departamentos específicos de $\mathrm{P} \& \mathrm{D}$ e a idade média das firmas. 
Tabela 1 - Características das Firmas Inovadoras e Não Inovadoras.

\begin{tabular}{|c|c|c|c|c|c|}
\hline \multirow[b]{2}{*}{ Ano } & \multirow[b]{2}{*}{ Variável } & \multicolumn{2}{|c|}{ Exportadoras } & \multicolumn{2}{|c|}{ Não Exportadoras } \\
\hline & & Inovadoras & $\begin{array}{c}\text { Não } \\
\text { Inovadoras } \\
\end{array}$ & Inovadoras & $\begin{array}{c}\text { Não } \\
\text { Inovadoras } \\
\end{array}$ \\
\hline \multirow{8}{*}{1996} & Tamanho & $\begin{array}{c}410,68 \\
(713,93)\end{array}$ & $\begin{array}{c}230,15 \\
(371,91)\end{array}$ & $\begin{array}{c}103,38 \\
(205,90)\end{array}$ & $\begin{array}{c}56,29 \\
(156,49)\end{array}$ \\
\hline & Produtividade & $\begin{array}{c}39.220,48 \\
(38.473,23)\end{array}$ & $\begin{array}{c}35.139,56 \\
(52.937,36)\end{array}$ & $\begin{array}{c}22.950,09 \\
(29.533,33)\end{array}$ & $\begin{array}{c}18.144,8 \\
(54.281,88)\end{array}$ \\
\hline & Trabalho Qualificado & $\begin{array}{l}0,25 \\
(0,16)\end{array}$ & $\begin{array}{c}0,23 \\
(0,17)\end{array}$ & $\begin{array}{c}0,19 \\
(0,17)\end{array}$ & $\begin{array}{c}0,14 \\
(0,16)\end{array}$ \\
\hline & Número de Patentes & 396 & 0 & 757 & 0 \\
\hline & P\&D & 457 & 44 & 317 & 40 \\
\hline & $\begin{array}{c}\text { Participação } \\
\text { estrangeira no capital }\end{array}$ & 224 & 111 & 75 & 65 \\
\hline & Idade Média & $\begin{array}{c}27,08 \\
(17,79)\end{array}$ & $\begin{array}{c}26,26 \\
(15,07)\end{array}$ & $\begin{array}{c}19,37 \\
(14,45)\end{array}$ & $\begin{array}{c}17,21 \\
(12,68)\end{array}$ \\
\hline & Firmas & 1008 & 696 & 2304 & 5290 \\
\hline \multirow{8}{*}{2001} & Tamanho & $\begin{array}{c}390,41 \\
(785,41)\end{array}$ & $\begin{array}{c}179,57 \\
(331,96)\end{array}$ & $\begin{array}{c}92,33 \\
(279,28)\end{array}$ & $\begin{array}{c}48,32 \\
(96,04)\end{array}$ \\
\hline & Produtividade & $\begin{array}{c}69.333,22 \\
(92.436,23)\end{array}$ & $\begin{array}{c}47.673,68 \\
(84.551,78)\end{array}$ & $\begin{array}{c}34.901,49 \\
(80.403,87)\end{array}$ & $\begin{array}{c}21.896,65 \\
(54.365,45)\end{array}$ \\
\hline & Trabalho Qualificado & $\begin{array}{c}0,24 \\
(0,15)\end{array}$ & $\begin{array}{c}0,21 \\
(0,17)\end{array}$ & $\begin{array}{c}0,18 \\
(0,15)\end{array}$ & $\begin{array}{c}0,14 \\
(0,15)\end{array}$ \\
\hline & Número de Patentes & 427 & 0 & 342 & 0 \\
\hline & P\&D & 613 & 326 & 612 & 624 \\
\hline & $\begin{array}{c}\text { Participação } \\
\text { estrangeira no capital }\end{array}$ & 217 & 219 & 39 & 77 \\
\hline & Idade Média & $\begin{array}{c}27,19 \\
(17,65)\end{array}$ & $\begin{array}{c}25,34 \\
(16,83)\end{array}$ & $\begin{array}{c}20,23 \\
(14,71)\end{array}$ & $\begin{array}{c}17,98 \\
(13,67)\end{array}$ \\
\hline & Firmas & 862 & 1390 & 1174 & 6307 \\
\hline
\end{tabular}

* Os desvios-padrão estão entre parênteses.

Fonte: Elaborada a partir de dados da PAEP 1996 e 2001.

Para o ano de 1996, das 9.298 firmas, 3.312 são inovadoras, ou seja, 35,6\% do total de firmas. Das firmas inovadoras, 1.008 firmas exportam, ou 30,43\% das firmas inovadoras. As firmas inovadoras são maiores, mais produtivas e possuem, em média, mais trabalho 
qualificado que as firmas não inovadoras. Situação similar é encontrada nas firmas da amostra de 2001.

Para o ano de 2001, 2.036 firmas são inovadoras. Das firmas inovadoras, 862 exportam, aproximadamente 42\% das firmas inovadoras. Em comparação com o ano de 1996, houve um aumento, proporcionalmente, das firmas inovadoras que exportam. As firmas inovadoras também são mais produtivas e possuem maior parcela de trabalhadores qualificados. Dentre as firmas inovadoras, as que exportam são maiores, mais produtivas e possuem maior parcela de trabalho qualificado nos dois anos.

O número de patentes registradas é bem reduzido. Em 1996, aproximadamente 23\% das firmas exportadoras apresentaram registro de patente, enquanto que em 2001, apenas 19\% das firmas exportadoras apresentaram alguma patente. Entre as firmas não exportadoras, no ano de 1996, 9,96\% das firmas apresentaram registro de patente, enquanto apenas 4,6\% das firmas não exportadoras apresentaram algum registro de patente no ano de 2001. Características semelhantes são encontradas quanto ao departamento específico de P\&D. Em 1996, 29,4\% das firmas exportadoras e 7,9\% das firmas não exportadoras apresentaram um departamento específico de P\&D. Em 2001 houve um aumento de P\&D formal nas empresas. Das firmas exportadoras, $41,7 \%$ apresentaram P\&D formal. Entre as não exportadoras, $16,5 \%$ apresentaram P\&D formal.

As firmas com participação estrangeira no capital representam, aproximadamente, 5,1\% da amostra em 1996. Em 2001 esta participação elevou-se para 5,7\%. Das firmas exportadoras, aproximadamente 19,4\% apresentaram participação estrangeira, em ambos os anos. As firmas não exportadoras apresentaram, aproximadamente, 1,6\% de participação estrangeira no capital, em ambos os anos. As firmas exportadoras são, em média, mais velhas que as firmas não exportadoras. Para ambos os anos, a idade média de uma firma exportadora é de 26 anos, enquanto que para as firmas não exportadoras, a idade média é de 18 anos. 
A Tabela 2 apresenta as características das firmas exportadoras e não exportadoras classificadas conforme o grau tecnológico para os anos de 1996 e 2001. As empresas foram identificadas como sendo de alto e baixo grau tecnológico baseado no setor que pertenciam ${ }^{16}$.

Tabela 2 - Características da Firmas de alto e baixo grau tecnológico.

\begin{tabular}{|c|c|c|c|c|c|}
\hline \multirow{3}{*}{ Ano } & \multirow{3}{*}{ Variável } & \multirow{2}{*}{\multicolumn{2}{|c|}{$\begin{array}{c}\text { Exportadoras } \\
\text { Grau Tecnológico }\end{array}$}} & \multirow{2}{*}{\multicolumn{2}{|c|}{$\begin{array}{l}\text { Não Exportadoras } \\
\text { Grau Tecnológico }\end{array}$}} \\
\hline & & & & & \\
\hline & & Alto & Baixo & Alto & Baixo \\
\hline \multirow{4}{*}{1996} & Tamanho & $\begin{array}{c}317,69 \\
(615,05)\end{array}$ & $\begin{array}{c}352,70 \\
(596,04)\end{array}$ & $\begin{array}{c}72,42 \\
(161,09)\end{array}$ & $\begin{array}{c}69,81 \\
(179,58)\end{array}$ \\
\hline & Produtividade & $\begin{array}{c}45.040,83 \\
(43.554,87)\end{array}$ & $\begin{array}{c}31.424,82 \\
(45.217,14)\end{array}$ & $\begin{array}{c}27.239,68 \\
(64.893,61)\end{array}$ & $\begin{array}{c}16.399,47 \\
(38.669,41)\end{array}$ \\
\hline & Trabalho Qualificado & $\begin{array}{c}0,29 \\
(0,19)\end{array}$ & $\begin{array}{c}0,20 \\
(0,14)\end{array}$ & $\begin{array}{c}0,20 \\
(0,19)\end{array}$ & $\begin{array}{c}0,14 \\
(0,15)\end{array}$ \\
\hline & Firmas & 767 & 937 & 2244 & 5350 \\
\hline \multirow{4}{*}{2001} & Tamanho & $\begin{array}{c}270,77 \\
(595,26)\end{array}$ & $\begin{array}{c}253,5 \\
(537,45)\end{array}$ & $\begin{array}{c}62,03 \\
(190,25)\end{array}$ & $\begin{array}{c}52,97 \\
(122,36)\end{array}$ \\
\hline & Produtividade & $\begin{array}{l}72.567,29 \\
(86.066,5)\end{array}$ & $\begin{array}{l}45.255,47 \\
(88.036,5)\end{array}$ & $\begin{array}{c}32.815,41 \\
(69.570,41)\end{array}$ & $\begin{array}{c}20.997,69 \\
(55.312,03)\end{array}$ \\
\hline & Trabalho Qualificado & $\begin{array}{c}0,27 \\
(0,18)\end{array}$ & $\begin{array}{c}0,19 \\
(0,14)\end{array}$ & $\begin{array}{c}0,18 \\
(0,17)\end{array}$ & $\begin{array}{c}0,13 \\
(0,14)\end{array}$ \\
\hline & Firmas & 883 & 1369 & 1861 & 5620 \\
\hline
\end{tabular}

* Os desvios-padrão estão entre parênteses.

Fonte: Elaborada a partir de dados da PAEP 1996 e 2001.

A Tabela 2 mostra que somente 28,2\% das empresas contidas na amostra de 2001 são de alto grau tecnológico, enquanto $71,8 \%$ das empresas são de baixo grau tecnológico. As firmas de alto grau tecnológico mostraram-se maiores, mais produtivas e com maior participação de trabalho qualificado quando comparadas com as firmas de baixo grau tecnológico. Entre as firmas de alto grau tecnológico, as firmas exportadoras são maiores, mais produtivas e possuem mais trabalho qualificado. Para as firmas de baixo grau tecnológico, as firmas exportadoras também são maiores, mais produtivas e possuem mais

\footnotetext{
${ }^{16}$ Foram classificados como de alto grau tecnológico os setores de química, petroquímica, mecânica, tecnologia e computação, eletrônica, telecomunicações, aparelhos médicos e serviços de transporte. Os demais setores foram classificados como de baixo grau tecnológico.
} 
trabalho qualificado quando comparadas com as firmas de baixo grau tecnológico não exportadoras.

Com base na amostra de 1996 e 2001, de forma geral, as empresas exportadoras são maiores, mais produtivas e possuem maior participação de trabalho qualificado. Entre as firmas exportadoras há maior participação de firmas inovadoras, com patentes e departamento específico de $\mathrm{P} \& D$ do que entre as firmas não exportadoras. Maior participação de capital estrangeiro também é encontrada entre as firmas exportadoras e são, em geral, mais maduras.

O modelo utilizado nesta pesquisa será apresentado na próxima seção.

\subsection{MODELO}

Para a estimativa dos parâmetros das variáveis explicativas foram utilizadas três variáveis proxies para representar a inovação tecnológica no modelo. A primeira foi a realização de inovação no período, independente da fonte deste desenvolvimento (fonte interna, clientes, concorrentes, universidades e outros) ou do tipo de inovação (produto ou processo, para a empresa ou para o mercado). A segunda variável foi o registro de patentes e a terceira foi a realização de atividade interna de pesquisa e desenvolvimento.

O modelo proposto neste trabalho é representado conforme a expressão (4.10):

$$
\begin{aligned}
& P\left(Y=1 \mid \text { Tam, Tam }{ }^{2} \text {,Prod,Quali,CE,Ida,Imp,Prop,Tec }\right)= \\
& \varphi\left(\alpha+\beta_{1} \text { Tam }+\beta_{2} \text { Tam }^{2}+\beta_{3} \text { Prod }+\beta_{4} \text { Quali }+\beta_{5} \text { CE }+\beta_{6} \text { Ida }+\beta_{7} \text { Imp }+\beta_{8} \text { Prop }+\beta_{9} \text { Tec }\right)
\end{aligned}
$$

em que $Y=1$ se a firma exporta e $Y=0$ se não exporta; Tam corresponde à variável tamanho; $\operatorname{Tam}^{2}$ corresponde ao tamanho ao quadrado; Prod é a produtividade média do trabalho em reais; Quali é a proporção de trabalhadores não ligados à produção; $C E$ é uma variável dummy que indica se há participação de capital estrangeiro; Ida é a idade da firma em anos; Imp é uma variável dummy que indica se a empresa importou no período; Prop 
corresponde aos gastos com propaganda e $T e c$ representa inovação tecnológica. A variável Tec representa as três variáveis tecnológicas de inovação: Inov, é uma variável dummy que indica a realização de inovação no período; Pat, é uma variável dummy que representa o registro de patentes no período e $P D$, é uma variável dummy que representa que a firma realiza internamente pesquisa e desenvolvimento

Para melhor compreender os efeitos dos indicadores selecionados sobre a probabilidade de exportar, é interessante dividir a amostra em grupos mais homogêneos, o que permite melhor análise dos resultados. O trabalho propõe classificar as firmas de acordo com o grau tecnológico. As firmas foram identificadas como sendo de alto ou baixo grau tecnológico baseado no setor a que pertenciam. Firmas dos setores de química, petroquímica, mecânica, tecnologia e computação, eletrônica, telecomunicações, aparelhos médicos e serviços de transporte foram classificadas como de alto grau tecnológico. As firmas dos demais setores foram classificados como de baixo grau tecnológico.

Diante dos modelos apresentados, a próxima sessão apresenta a análise dos resultados obtidos.

\subsection{ANÁliSe ECONÔMICA dOS RESULTADOS}

A partir da amostra descrita e dos métodos propostos foram realizadas regressões para avaliar o impacto das variáveis explicativas sobre a probabilidade de uma empresa exportar. As estimativas foram obtidas considerando os métodos Probit e Logit, utilizando dados referentes aos anos de 1996 e 2001.

As estimativas dos parâmetros estão reportadas na Tabela 3. O método utilizado não alterou o sinal dos parâmetros das variáveis nem o nível de significância destes parâmetros. Desta forma, serão apresentados os parâmetros estimados apenas pelo método Probit para os anos de 1996 e 2001 
Tabela 3 - Resultados da estimação do modelo Probit para os anos de 1996 e 2001

\begin{tabular}{|c|c|c|c|c|c|c|}
\hline \multirow{2}{*}{ Variáveis } & \multicolumn{2}{|c|}{ Modelo 1} & \multicolumn{2}{|c|}{ Modelo 2} & \multicolumn{2}{|c|}{ Modelo 3} \\
\hline & 1996 & 2001 & 1996 & 2001 & 1996 & 2001 \\
\hline Intercepto & $\begin{array}{c}-1.851 * * * \\
(0.039)\end{array}$ & $\begin{array}{c}1.614 * * * \\
(0.034)\end{array}$ & $\begin{array}{c}-1.448 * * * \\
(0.059)\end{array}$ & $\begin{array}{c}-1.584 * * * \\
(0.033)\end{array}$ & $\begin{array}{c}-0.968 * * * \\
(0.0741)\end{array}$ & $\begin{array}{c}-1.622 * * * \\
(0.034)\end{array}$ \\
\hline Tam & $\begin{array}{c}0.002 * * * \\
(0.0001)\end{array}$ & $\begin{array}{c}0.002 * * * \\
(0.0001)\end{array}$ & $\begin{array}{l}0.00004 \\
(0.0001)\end{array}$ & $\begin{array}{c}0.002 * * * \\
(0.0001)\end{array}$ & $\begin{array}{c}0.0006 * * * \\
(0.00009)\end{array}$ & $\begin{array}{c}0.002 * * * \\
(0.0001)\end{array}$ \\
\hline $\operatorname{Tam}^{2}$ & $\begin{array}{c}-2.97 \mathrm{E}-7 * * * \\
(3.37 \mathrm{E}-8)\end{array}$ & $\begin{array}{c}-2.81 \mathrm{E}-7 * * * \\
(2.76 \mathrm{E}-8)\end{array}$ & $\begin{array}{l}-1.07 \mathrm{E}-8 \\
(2.74 \mathrm{E}-8)\end{array}$ & $\begin{array}{c}-2.85 \mathrm{E}-7 * * * \\
(2.79 \mathrm{E}-8)\end{array}$ & $\begin{array}{c}-4.38 \mathrm{E}-8 * * * \\
(9.473 \mathrm{E}-9)\end{array}$ & $\begin{array}{c}-2.79 \mathrm{E}-7^{* * * *} \\
(2.77 \mathrm{E}-8)\end{array}$ \\
\hline Prod & $\begin{array}{c}4.61 \mathrm{E}-12 \\
(6.48 \mathrm{E}-12)\end{array}$ & $\begin{array}{l}1.73 \mathrm{E}-11 * * \\
(5.62 \mathrm{E}-12)\end{array}$ & $\begin{array}{l}1.8 \mathrm{E}-11 * \\
(9.5 \mathrm{E}-12)\end{array}$ & $\begin{array}{c}1.87 \mathrm{E}-11 * * * \\
(5.62 \mathrm{E}-12)\end{array}$ & $\begin{array}{c}-105 \mathrm{E}-13 \\
(1.19 \mathrm{E}-11)\end{array}$ & $\begin{array}{l}1.75 \mathrm{E}-11 * * \\
(5.63 \mathrm{E}-12)\end{array}$ \\
\hline Quali & $\begin{array}{c}2.08 \mathrm{E}-10 * * \\
(1.06 \mathrm{E}-10)\end{array}$ & $\begin{array}{c}5.57 \mathrm{E}-10 * * * \\
(1.08 \mathrm{E}-10)\end{array}$ & $\begin{array}{c}4.27 \mathrm{E}-11 \\
(1.47 \mathrm{E}-10)\end{array}$ & $\begin{array}{c}5.51 \mathrm{E}-10 * * * \\
(1.08 \mathrm{E}-10)\end{array}$ & $\begin{array}{l}-555 \mathrm{E}-12^{*} \\
(1.69 \mathrm{E}-10)\end{array}$ & $\begin{array}{c}5.22 \mathrm{E}-10 * * * \\
(1.08 \mathrm{E}-10)\end{array}$ \\
\hline$C E$ & $\begin{array}{c}0.763 * * * \\
(0.073)\end{array}$ & $\begin{array}{c}0.745 * * * \\
(0.075)\end{array}$ & $\begin{array}{c}0.892 * * * \\
(0.093)\end{array}$ & $\begin{array}{c}0.731 * * * \\
(0.076)\end{array}$ & $\begin{array}{c}0.722 * * * \\
(0.099)\end{array}$ & $\begin{array}{c}0.748 * * * \\
(0.075)\end{array}$ \\
\hline Ida & $\begin{array}{c}0.011 * * * \\
(0.001)\end{array}$ & $\begin{array}{c}0.012 * * * \\
(0.001)\end{array}$ & $\begin{array}{c}0.017 * * * \\
(0.001)\end{array}$ & $\begin{array}{c}0.012 * * * \\
(0.001)\end{array}$ & $\begin{array}{c}0.009 * * * \\
(0.002)\end{array}$ & $\begin{array}{c}0.012 * * * \\
(0.001)\end{array}$ \\
\hline $\operatorname{Imp}$ & $\begin{array}{c}0.917 * * * \\
(0.041)\end{array}$ & $\begin{array}{c}1.066^{* * * *} \\
(0.047)\end{array}$ & $\begin{array}{c}0.906 * * * \\
(0.053)\end{array}$ & $\begin{array}{c}1.085^{* * * *} \\
(0.047)\end{array}$ & $\begin{array}{c}0.828 * * * \\
(0.062)\end{array}$ & $\begin{array}{c}1.037 * * * \\
(0.047)\end{array}$ \\
\hline Prop & $\begin{array}{c}-3.74 \mathrm{E}-9 * * \\
(1.54 \mathrm{E}-9)\end{array}$ & $\begin{array}{l}5.22 \mathrm{E}-10 \\
(1.18 \mathrm{E}-9)\end{array}$ & $\begin{array}{c}-243 \mathrm{E}-12 \\
(1.53 \mathrm{E}-10)\end{array}$ & $\begin{array}{l}3.52 \mathrm{E}-10 \\
(1.19 \mathrm{E}-9)\end{array}$ & $\begin{array}{c}-5.22 \mathrm{E}-9 * * * \\
(1.87 \mathrm{E}-9)\end{array}$ & $\begin{array}{l}5.13 \mathrm{E}-10 \\
(1.18 \mathrm{E}-9)\end{array}$ \\
\hline Inov & $\begin{array}{c}0.341^{* * * *} \\
(0.036)\end{array}$ & $\begin{array}{c}0.358 * * * \\
(0.038)\end{array}$ & 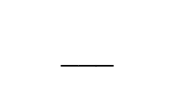 & - & 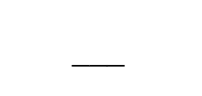 & - \\
\hline Pat & - & - & $\begin{array}{c}0.159 * * \\
(0.052)\end{array}$ & $\begin{array}{c}0.504 * * * \\
(0.057)\end{array}$ & $\overline{ }$ & - \\
\hline$P D$ & - & - & - & - & $\begin{array}{c}0.277 * * * \\
(0.061)\end{array}$ & $\begin{array}{c}0.384 * * * \\
(0.037)\end{array}$ \\
\hline $\mathrm{N}^{\mathrm{o}}$ de Firmas & 9298 & 9733 & 3415 & 9733 & 2225 & 9733 \\
\hline AIC & 6473.453 & 7865.280 & 3392.254 & 7874.236 & 2524.684 & 7847.972 \\
\hline
\end{tabular}

Notas: (1) Erro padrão entre parênteses; (2) Nível de significância: 1\% (***), 5\% (**), 10\% (*); (3) A variável Tam representa o tamanho da firma; Prod representa a produtividade do trabalho; Quali representa a proporção de trabalho qualificado; $C E$ representa participação estrangeira no capital; Ida representa a idade da firma, Imp representa importação; Prop representa gastos com propaganda; Inov representa inovação; Pat representa patente e $P D$ representa pesquisa e desenvolvimento

Os resultados indicaram que para as firmas industriais paulistas o tamanho da empresa contribui de forma positiva e significativa para explicar a probabilidade da firma exportar. Entretanto, o parâmetro estimado para a variável tamanho para o modelo 2 no ano de 1996 não mostrou-se significativo para explicar a probabilidade de exportar. $\mathrm{O}$ papel positivo do 
tamanho da empresa estaria associado aos ganhos de escala e à maior capacidade de arcar com os custos de entrada no mercado internacional bem como com as incertezas inerentes a este mercado. Neste sentido, empresas maiores seriam mais prováveis de exportar.

A estimativa correspondente ao coeficiente da variável tamanho na forma quadrática foi negativa e significativa para explicar a probabilidade de exportar. Com o aumento do tamanho da empresa há também o aumento dos custos para manter suas atividades. Este aumento do tamanho da empresa é interessante apenas enquanto o ganho marginal de aumentar o tamanho for maior que o aumento marginal dos custos. Desta forma, acredita-se que o tamanho da empresa tenha uma relação positiva, mas não linear, com a probabilidade de exportar.

Para o ano de 1996, a produtividade do trabalho apresentou-se significativa para explicar a probabilidade de exportar apenas no modelo 2, quando se considera patente como variável tecnológica. Para o ano de 2001, o parâmetro da variável produtividade apresentou-se positivo e significativo para explicar a probabilidade de exportar nos três modelos. A produtividade do trabalho está relacionada aos custos da empresa. Quanto maior a produtividade do trabalho, mais um trabalhador consegue produzir com uma quantidade de insumo. Isto pode gerar redução de custos, o que contribuiria para a inserção da firma no mercado internacional por meio de preços mais competitivos e mais condições de arcar com os gastos para entrada no mercado internacional.

Com base nestes resultados, acredita-se que em 1996, a produtividade do trabalho não era um fator determinante para a atividade exportadora. Uma possível razão para os diferentes resultados obtidos para esta variável no ano de 2001 é que nos primeiros anos após a abertura comercial as empresas realizaram uma forte reestruturação no âmbito produtivo e administrativo das empresas. Novas técnicas foram implementadas a fim de alcançar melhorias na competitividade das empresas em aspectos como redução de custos, utilização 
mais eficiente de insumos, eliminação de gargalos e redução de desperdícios. Como conseqüências destas medidas houve um aumento da produtividade, o que, aparentemente, explica o fato de esta variável tornar-se significativa para explicar a probabilidade de exportar em 2001.

A qualificação do trabalho apresentou resultados distintos entre modelos para o ano de 1996. Para o modelo 1, que considera como variável tecnológica a inovação, a variável apresentou parâmetro positivo e significativo para explicar a probabilidade de exportar. Para o modelo 2, que considera patentes como variável tecnológica, a qualificação do trabalho não mostrou-se significativa e para o modelo 3, que considera P\&D como variável tecnológica, o parâmetro mostrou-se negativo e significativo para explicar a probabilidade de exportar. Entretanto, as estimativas para os parâmetros da variável trabalho qualificado para o ano de 2001 apresentaram-se positivas e significativas para explicar a probabilidade de exportar nos três modelos. Isto pode indicar que, em 1996, a qualificação do trabalho não era um aspecto determinante da atividade exportadora paulista, ou ainda, que as empresas exportadoras eram mais competitivas em mercados em que predominavam produtos que requeriam mão-de-obra menos qualificada.

A partir de 1996, as empresas investiram na reposição de equipamentos, eliminação de desperdícios e desobstrução de gargalos, ações que contribuíram para a redução de custos e para a modernização. É possível que o investimento em equipamentos mais modernos tenha exigido maior qualificação do trabalho, o que justificaria a contribuição positiva do trabalho qualificado para a atividade exportadora em 2001. Por fim, há a possibilidade de que a proxy utilizada para representar a qualificação do trabalho não tenha sido capaz de capturar este aspecto.

A participação de capital estrangeiro no capital da firma apresentou impacto positivo e significativo para explicar a probabilidade de exportar. O parâmetro da variável apresentou 
sinal positivo e foi significativo nos três modelos. Uma possível razão seria o desenvolvimento de um canal de comercialização por meio da interação com a matriz. Além disto, podem haver vantagens da participação de capital estrangeiro em virtude de possível transferência de conhecimentos gerenciais, tecnologia, capacidade mercadológica e outros. Este conhecimento adquirido poderia, portanto, facilitar a inserção das firmas no comércio internacional.

A variável idade da firma apresentou parâmetro positivo e significativo para explicar a atividade exportadora. A idade da firma pode indicar competitividade passada, pois empresas mais eficientes são mais prováveis de sobreviver. Em razão desta eficiência, empresas mais maduras e com maior experiência adquirida seriam mais prováveis de exportar.

A variável dummy de importação obteve parâmetro positivo e significativo para explicar a probabilidade de exportar. A importação, possivelmente, facilita o desenvolvimento de canais de comercialização, exige que a empresa mantenha uma estrutura legal adequada a relações com o exterior, bem como contribui para um melhor conhecimento de características de produtos e mercados internacionais. Este conhecimento sobre preferências de mercados internacionais, a estrutura legal e os canais de comercialização desenvolvidos, contribuiriam para uma firma comercializar com o mercado externo.

O parâmetro da variável gastos com propaganda apresentou-se negativo e significativo para explicar a probabilidade de exportar para os modelos 1 e 3 para o ano de 1996. Para o ano de 2001 a variável não foi significativa. Considerando estes resultados, acredita-se que os gastos com propaganda possam estar relacionados à construção de imagem e promoção de vendas no mercado interno e, por isto, não contribuiriam para a atividade exportadora. Há também alguma limitação da PAEP que pode contribuir para este resultado. O valor dos gastos com propaganda e publicidade obtidos da pesquisa PAEP contemplam a importância gasta em anúncios ou publicações em rádios, televisão e empresas jornalísticas. A distribuição 
de amostras em feiras ou outro tipo de promoção que utilize a distribuição de produtos não são considerados na pesquisa. Isto prejudica a avaliação da contribuição da propaganda em setores que utilizam estas formas de promoção, como por exemplo, o setor químico ou farmacêutico.

As variáveis que representam inovação tecnológica, ou seja, inovação, patente e P\&D, apresentaram-se positivas e significativas para explicar a probabilidade de exportar. As variáveis de inovação tecnológica estariam relacionadas à construção de conhecimento, geração de novos produtos e processos e maior competitividade. Assim, a inovação tecnológica e variáveis que estão presentes no processo de inovação, podem aumentar a competitividade da firma, além de contribuir para a participação em novos mercados.

Quanto à classificação das firmas por grau tecnológico, os resultados das estimativas para as firmas de alto e baixo grau tecnológico são apresentados nas tabelas E e F do anexo. Os resultados das estimativas por grau tecnológico são muito similares aos resultados encontrados para a amostra toda. De forma geral, o tamanho apresenta uma relação positiva, mas não linear, com a probabilidade de exportar. A produtividade do trabalho não mostrou-se significativa para as firmas de alto e baixo grau tecnológico no ano de 1996. Para o ano de 2001, entretanto, a produtividade do trabalho apresentou-se positiva e significativa para explicar a probabilidade de exportar de empresas de alto e baixo grau tecnológico. Isto pode indicar que o papel da produtividade na atividade exportadora não esteja relacionado a algum setor específico, mas sim aos produtos exportados pelas empresas nos anos de 1996 e 2001 .

As variáveis que representam a participação estrangeira no capital, idade da firma e importação de produtos apresentaram impacto positivo e significativo para explicar a probabilidade de exportar. Estes resultados se mantêm independente do grau tecnológico. Os resultados podem indicar que a transferência de capital e conhecimento provenientes da participação estrangeira no capital da firma beneficiem todas as firmas, independente do grau 
tecnológico do seu setor. Da mesma forma, a experiência adquirida com a trajetória da firma e os canais de comercialização desenvolvidos com a importação de produtos parecem beneficiar todas as firmas, independente do seu grau tecnológico.

As variáveis que representam inovação tecnológica apresentaram-se positivas e significativas para explicar a probabilidade de exportar de empresas de alto e baixo grau tecnológico. Estes resultados sugerem que, para as indústrias paulistas, a inovação tecnológica contribui de forma positiva para as exportações de empresas de alto e baixo grau tecnológico. Desta forma, a inovação tecnológica traz benefícios a todas as empresas, independente do seu setor.

A variável gastos com propaganda apresentou resultados distintos para as firmas de alto e baixo grau tecnológico. Para as firmas de alto grau tecnológico, a variável apresentouse negativa e significativa para explicar a probabilidade de exportar. Entretanto, para as firmas de baixo grau tecnológico, a variável mostrou-se positiva e significativa para explicar a probabilidade de exportar. Conforme explicado anteriormente, a PAEP considerou como propaganda e publicidade apenas os gastos com anúncios ou publicações. Desta forma, empresas de setores de química, farmacêutico, laboratórios e outros, que utilizam a distribuição de amostras a clientes ou participação em feiras como forma de propaganda, tiveram sua análise prejudicada quanto a esta variável. Muitos destes setores são de alto grau tecnológico, o que pode explicar o impacto negativo desta variável para as empresas de alto grau tecnológico. Para as firmas de baixo grau tecnológico, acredita-se que a forma de propaganda avaliada na pesquisa, anúncios e publicações, contribuam de forma positiva para a atividade exportadora.

A análise realizada permitiu a elaboração de três modelos diferentes. Neste sentido, torna-se relevante a utilização de um critério de seleção de modelos para escolher o modelo mais apropriado estatisticamente para explicar a probabilidade de uma empresa exportar. Foi 
utilizado o AIC (Akaike information criterion) para verificação do modelo mais adequado. Para interpretação do AIC pode-se comparar o valor referente ao teste de cada modelo. O modelo mais adequado estatisticamente para explicar a probabilidade de exportar é aquele que apresenta o menor valor para o teste. De acordo com os valores apresentados na tabela 3, o modelo 3, que utiliza P\&D para representar inovação tecnológica, parece ser o mais adequado tanto para o ano de 1996 quanto para o ano de 2001. Desta forma, para o conjunto de dados utilizado, a variável P\&D parece representar melhor o processo de inovação tecnológica.

Embora os dados utilizados neste trabalho tenham sido coletados há algum tempo, com base nas estimativas realizadas e na análise de trabalhos semelhantes que utilizaram dados mais recentes, acredita-se que algumas variáveis sejam determinantes da atividade exportadora no período atual, independente das diferenças no cenário econômico. As variáveis tamanho da firma, participação estrangeira no capital, idade da firma, importação e inovação tecnológica apresentaram os mesmos resultados independente da época analisada (1996 e 2001) e os estudos de Carneiro (2002), De Negri (2005), Araujo e Pianto (2006), Kannebley e Valeri (2006) e Kannebley et al (2009) corroboram os resultados obtidos com a amostra da PAEP para o estado de São Paulo.

A partir dos resultados expostos, o próximo capítulo apresenta as conclusões do trabalho. 


\section{CONCLUSÃo}

O presente trabalho teve por objetivo identificar os determinantes da atividade exportadora de firmas industriais paulistas. Esta análise utilizou dados disponíveis na Pesquisa da Atividade Econômica Paulista (PAEP) realizada em 1996 e 2001 pela Fundação Estadual de Análise de Dados (SEADE). A amostra do ano de 1996 é composta por 9.298 firmas e a amostra do ano de 2001 é composta por 9.733 firmas. A pesquisa teve como objetivo secundário identificar se diferentes proxies utilizadas para representar inovação poderiam apresentar resultados distintos. A partir dos objetivos propostos elaborou-se um modelo econométrico para avaliar os determinantes da atividade exportadora. 
No ano de 1996 , quando foi realizada a primeira pesquisa, a indústria estava em um período caracterizado por um aumento dos investimentos em capital fixo e eficiência. No ano de 2001, após a desvalorização do câmbio, o cenário macroeconômico se apresentava diferente e havia uma crise energética no país. Desta forma os dois períodos de coleta dos dados apresentavam características distintas, o que levou as empresas a adotarem estratégias competitivas diferentes. A análise dos determinantes da atividade exportadora nestes dois momentos contribui para um melhor mapeamento das estratégias adotadas e das condições competitivas da indústria no mercado internacional. Os resultados destas análises são informações importantes para a elaboração de políticas públicas efetivas para a inserção da indústria no comércio internacional.

Os resultados da pesquisa indicam que o tamanho da empresa apresenta impacto positivo, mas não linear, sobre a probabilidade de exportar no ano de 1996 e 2001. A produtividade do trabalho e a qualificação do trabalho apresentam comportamentos diferentes em 1996 e 2001. Para o ano de 1996, a produtividade do trabalho contribui de forma positiva para explicar a probabilidade de exportar apenas quando a variável tecnológica patente é considerada. Para o ano de 2001, o parâmetro da variável produtividade apresentou-se positivo e significativo para explicar a probabilidade de exportar, independente da variável tecnológica considerada. Em função das condições enfrentadas pelas empresas em 1996, da introdução de técnicas para melhorar a competitividade das empresas, aparentemente a produtividade do trabalho não era uma característica que contribuísse para a inserção no comércio internacional. Como conseqüências da introdução de novas técnicas e aquisição de equipamentos mais modernos, houve um aumento da produtividade, o que, possivelmente, contribuiu para o fato de esta variável tornar-se significativa para explicar a probabilidade de exportar em 2001. 
A qualificação do trabalho apresentou resultados distintos para os anos de 1996 e 2001. Em 1996, o parâmetro desta variável apresentou-se positivo, não significativo e negativo, ou seja, um resultado diferente para cada variável tecnológica considerada. Entretanto, as estimativas para os parâmetros da variável trabalho qualificado para o ano de 2001 indicam um impacto positivo para explicar a probabilidade de exportar. Estes resultados sugerem que em 1996, as empresas exportadoras eram mais competitivas em mercados em que predominavam produtos que requeriam mão-de-obra menos qualificada, ou ainda, que a introdução de equipamentos mais modernos exigiu mão-de-obra mais qualificada para operá-lo.

A participação de capital estrangeiro no capital da firma, a idade da firma e a variável dummy que representa importação apresentaram coeficientes positivos e significativos para explicar a probabilidade de exportar nos dois anos, independente da variável tecnológica considerada. A participação estrangeira no capital poderia estar relacionada à transferência de capital e conhecimento, bem como melhores técnicas de gestão. A contribuição do aumento da idade da firma, possivelmente, estaria relacionada à experiência adquirida e a variável dummy de importação pode refletir o desenvolvimento de canais de comercialização.

Os gastos com propaganda, que estariam relacionados à diferenciação de produtos, não se mostraram significativos sendo até negativos para explicar a probabilidade de exportar de indústrias paulistas. Estes resultados podem indicar que a estratégia competitiva das indústrias de São Paulo não estaria pautada na diferenciação de produtos. Outra possível explicação é que a proxy utilizada não foi adequada, uma vez que ela pode estar voltada para a construção de imagem para o mercado interno. Há ainda uma deficiência na PAEP, a qual considera apenas anúncios e publicações em rádios, televisão e outras mídias como propaganda e publicidade. Assim, empresas que promovem seus produtos por meio de feiras e distribuição de amostras tiveram sua análise prejudicada por estes gastos não serem considerados na pesquisa. 
As três variáveis que representaram inovação tecnológica apresentaram-se positivas e significativas para explicar a probabilidade de exportar em 1996 e 2001 Desta forma, as diferentes proxies apontam na mesma direção, ou seja, de que a inovação tecnológica contribui de forma positiva para a inserção das firmas no mercado internacional. Entretanto, o critério utilizado para seleção de modelos indicou que o modelo que contempla P\&D explicou melhor a probabilidade de exportar. Desta forma, a variável P\&D seria mais adequada para representar inovação tecnológica.

Para melhor explorar o conjunto de dados disponível, trabalhos futuros podem analisar separadamente a inovação de produto e a inovação de processo. Além disto, uma análise setorial poderia ser mais adequada para a identificação do comportamento exportador em diferentes setores, uma vez que o agrupamento por grau tecnológico apresentou resultados muito semelhantes para os dois grupos.

Por fim, embora os dados utilizados neste trabalho tenham sido coletados há algum tempo, seus resultados são corroborados por estudos de Carneiro (2002), De Negri (2005), Araujo e Pianto (2006), Kannebley e Valeri (2006) e Kannebley et al (2009), sugerindo que também para o período atual, as variáveis tamanho da firma, participação estrangeira no capital, idade da firma, importação e inovação tecnológica sejam determinantes da atividade exportadora paulista. 


\section{REFERÊNCIAS BIBLIOGRÁFICAS}

ALVAREZ, R. Determinants of firm export performance in a less developed Country. Anderson Graduate School of Management, UCLA. Califórnia, 2003.

ARAÚJO, B. C. Os determinantes do comércio internacional ao nível da firma: evidências empíricas. Texto para discussão Ipea, n. 1.133, Brasília, 2005.

; PIANTO, D.M. Potencial exportador das firmas industriais brasileiras. Texto para discussão Ipea, n. 1.176, Brasília, 2006

ARBACHE, J. S. Comércio internacional, competitividade e políticas públicas no Brasil. Texto para discussão Ipea, n. 903, Brasília, 2002.

BARRIOS, S.; GÖRG, H.; STROBL, E. Explaining Firms Export Behaviour: the role of R\&D and spillovers. Working Paper, 2002/12, Fedea, 2002.

BAUMANN, R et al. Brasil, uma década em transição. Rio de Janeiro: Cepal: Campus, 2000.

BERNARD, A.; JENSEN, J. B. Exceptional export performance: cause, effect or both? Journal of International Economics, 47, 1-25,1999.

. Why some firms export? NBER Working Paper, Cambridge, MA n.8.349, 2001.

BIELSCHOWSKY, R. Investimento e reformas no Brasil: indústria e infra-estrutura nos anos 1990. Brasília: IPEA/CEPAL, 2002.

BISHOP, K. The first phase of the internationalisation process: export determinants in firms of the former Soviet Union. Working Paper, n. 2, London: University College London, Centre for the Study of Economic and Social Change in Europe, 2001.

CARNEIRO, F. G. Destino das exportações e canais de comercialização das maiores empresas brasileiras (1995/2000). Texto para discussão Ipea, n. 917, Brasília, 2002.

CLERIDES, S.; LAUCH, S.; TYBOUT, J. R. Is learning by exporting important? MicroDynamic evidence from Colombia, Mexico and Morocco. The Quarterly Journal of Economics, v. 113, n. 3, p. 903-947, 1998.

COMIN, A. Pequeno balanço da reestruturação industrial nos anos 90. In: I Ciclo de Debates em Economia Industrial, Trabalho e Tecnologia, 2003. Disponível em: http://www.pucsp.br/eitt/downloads/eitt2003_alexandrecomin.pdf.

DE NEGRI, F. Desempenho comercial das empresas estrangeiras no Brasil na década de 90. Prêmio BNDES de Economia, n. 26, Rio de Janeiro, 2004.

. Inovação tecnológica e exportações das firmas brasileiras. In: $33^{\circ}$ Encontro Nacional de Economia, 2005, Natal. Anais do 33 $^{\circ}$ Encontro Nacional de Economia, 2005. 
DE NEGRI, J. A.; FREITAS, F. Inovação tecnológica, eficiência de escala e exportações brasileiras. Texto para discussão Ipea, n. 1.044, Brasília, 2004.

DE NEGRI, J. A.; SALERNO, M.S. Inovações, padrões tecnológicos e desempenho das firmas industriais brasileiras. Brasília: Ipea, 2005.

DIJK, M. V. The determinants of export performance in developing countries: the case of Indonesian manufacturing. Working Paper, Eindhoven Centre for Innovation Studies, 2002.

ERBER, F. O padrão de desenvolvimento industrial e tecnológico e o futuro da indústria brasileira. Revista de Economia Contemporânea, vol. 5, no especial, UFRJ, 2001.

FAGERBERG, J. Technology and competitiveness. Oxford Review of Economic Policy, v. 12, n. 3. 1996.

FUNDO MONETÁRIO INTERNACIONAL. World Economic Outlook.Database - WEO Groups and Aggregates Information, 2009. Disponível em:

$<\underline{\text { http://www.imf.org/external/pubs/ft/weo/2009/01/weodata/groups.htm\#ae }}>$ Acesso em: 21

Set. 2009.

GONÇALVES, R; BAUMANN, R; CANUTO, O; PRADO, L.C.D. A Nova Economia Internacional: uma perspectiva brasileira. Rio de Janeiro: Campus, 1998.

GROSSMAN, G. M., HELPMAN, E. Technology and trade. Working paper, n. 4926, National Bureau of Economic Research - NBER, Cambridge, nov/1994.

GUIMARÃES, E. P. Evolução das teorias de comércio internacional. In Estudos em Comércio Exterior, v. I n. 2, UFRJ: Rio de Janeiro, jan-jun/1997.

GUMEDE, V. Export propensities and intensities of small and medium manufacturing enterprises in South Africa. Small Business Economics, v. 22, p. 379-389, 2004.

HIDALGO, A. B; MATA, D. Produtividade e Desempenho Exportador das Firmas na Indústria de Transformação Brasileira. Est. econ., v. 39, n. 4, p. 709-735, OUTUBRODEZEMBRO 2009.

KANNEBLEY JÚNIOR, S.; VALERI, J. O. Persistência e Permanência na Atividade Exportadora: Uma Análise Empírica para as Empresas Industriais Brasileiras. In: $34^{\circ}$ Encontro Nacional de Economia, 2006, Salvador. Anais do $3^{\circ}$ Encontro Nacional de Economia, 2006.

KANNEBLEY JÚNIOR, S.; ESTEVES, L. A.; SILVA, A. M. P; ARAUJO, B.C.O.P. Autoseleção e aprendizado no comércio exterior das firmas industriais brasileiras. In: $37^{\circ}$ Encontro Nacional de Economia, 2009, Foz do Iguaçu. Anais do $\mathbf{3 7}^{\mathbf{0}}$ Encontro Nacional de Economia, 2009.

KRUGMAN, P; OBSTFELD, M. Economia Internacional - Teoria e Política. São Paulo: MAKRON Books, 1999.

LEFEBVRE, E.; LEFEBVRE, L.; BORGAUT, M. R\&D-Related capabilities as determinants of export performance. Small Business Economics, v. 10, p. 365-377, 1998. 
LIU, X.; SHU, C. Determinants of export performance: evidence from Chinese industries. Economics of Planning, v. 33, p. 45-67, 2003.

OLIVEIRA, M. F.; TORKOMIAN, Ana Lucia Vitale. Aglomerações produtivas e internacionalização de pequenas empresas. Revista do Centro de Ciências Administrativas (UNIFOR), v. 11, p. 93-102, 2005.

ÖZÇELIK, E.; TAYMAZ, E. Does innovativeness matter for international competitiveness in developing countries? The case of Turkish manufacturing industries. Working Paper in Economics, Ankara, 01/07, 2001.

PARISI, M. L.; SCHIANTARELLI, F.; SEMBENELLI, A. Productivity, innovation creation and absorption, and R\&D: micro evidence for Italy. Department of Economics, Boston College, Chestnut Hill (MA), 2002.

PINDYCK, R S. RUBINFELD, D.L. Microeconomia. São Paulo: Pearson Prentice Hall, 2005.

PINHEIRO, A. C.; MOREIRA, M. M. O perfil dos exportadores brasileiros de manufaturados nos anos 90: quais as implicações de política? Texto para discussão BNDES, n. 80, Rio de Janeiro, 2000.

ROBERTS, M.; TYBOUT, J. R. The decision to export in Colombia: an empirical model of entry with sunk costs. The American Economic Review, v. 87, n. 4, p. 545-564, 1997.

ROPER, S.; LOVE, J. Innovation and export performance: evidence from Uk and German manufacturing plants. Working Paper, n. 62, Northern Ireland Economic Research Centre, 2001.

SEBRAE. Disponível em :

$<$ www.sebraesp.com.br/sites/default/files/classificacao empregado.pdf $>$ acesso em $06 \mathrm{de}$ agosto de 2009.

SJÖHOLM, F.; TAKII, S. Foreign networks and exports: results from Indonesian panel data. The Developing Economies, v. 46, n.4, p. 428-446, 2008.

STERLACCHINI, A. Do innovative activities matter to small firms in non-R\&D-intensive industries? An application to export performance. Research Policy, v. 28, p. 819-832, 1999.

STOCK, J.H; WATSON, M.W. Econometria. São Paulo: Addison Wesley, 2004.

WAGNER, J. Unobserved firm heterogeneity and the size-exports nexus: evidence from German panel data. HWWA Discussion Paper, n. 194, Hamburgo, 2002.

WAKELIN, K. Trade and Innovation: Theory and Evidence. Cheltenham: Edward Elgar, 1997. $841,1998$.

Innovation and export behaviour at the firm level. Research Policy, v. 26, p. 829-

YANG, C.; CHEN, J.; CHUANG, W. Technology and export decision. Small Business Economics, v. 22, p. 349-364, 2004. 


\section{ANEXO}

Tabela A - Características de micro empresas

\begin{tabular}{cccccc}
\hline \multirow{2}{*}{ Ano } & Variável & \multicolumn{2}{c}{ Firmas Exportadoras } & \multicolumn{2}{c}{$\begin{array}{c}\text { Firmas Não } \\
\text { Exportadoras }\end{array}$} \\
\cline { 3 - 6 } & Tamanho & 12,70 & 4,35 & 10,74 & 4,24 \\
\cline { 3 - 6 } 1996 & Produtividade & $33.184,89$ & $34.974,31$ & $17.015,65$ & $77.325,69$ \\
& Trabalho Qualificado & 0,19 & 0,19 & 0,10 & 0,14 \\
& Firmas & 71 & & 2357 & \\
\hline \multirow{2}{*}{2001} & Tamanho & 13,62 & 4,75 & 12,11 & 4,62 \\
& Produtividade & $43.743,70$ & $13.2196,80$ & $17.746,45$ & $39.494,21$ \\
& Trabalho Qualificado & 0,17 & 0,19 & 0,11 & 0,15 \\
& Firmas & 169 & & 2906 & \\
\hline
\end{tabular}

Tabela B - Características de pequenas empresas

\begin{tabular}{|c|c|c|c|c|c|}
\hline \multirow{2}{*}{ Ano } & \multirow{2}{*}{ Variável } & \multicolumn{2}{|c|}{ Firmas Exportadoras } & \multicolumn{2}{|c|}{$\begin{array}{l}\text { Firmas Não } \\
\text { Exportadoras }\end{array}$} \\
\hline & & Média & Desvio & Média & Desvio \\
\hline \multirow{4}{*}{1996} & Tamanho & 57,65 & 21,96 & 46,42 & 20,25 \\
\hline & Produtividade & $33.401,43$ & $50.660,01$ & $18.681,93$ & $24.274,51$ \\
\hline & Trabalho Qualificado & 0,24 & 0,18 & 0,16 & 0,15 \\
\hline & Firmas & 626 & & 4060 & \\
\hline \multirow{4}{*}{2001} & Tamanho & 57,30 & 22,04 & 47,30 & 19,91 \\
\hline & Produtividade & $49.878,44$ & $93.528,03$ & $26.048,03$ & $70.626,03$ \\
\hline & Trabalho Qualificado & 0,22 & 0,15 & 0,16 & 0,13 \\
\hline & Firmas & 967 & & 3814 & \\
\hline
\end{tabular}


Tabela C - Características de médias empresas

\begin{tabular}{|c|c|c|c|c|c|}
\hline \multirow[t]{2}{*}{ Ano } & \multirow[t]{2}{*}{ Variável } & \multicolumn{2}{|c|}{ Firmas Exportadoras } & \multicolumn{2}{|c|}{$\begin{array}{c}\text { Firmas Não } \\
\text { Exportadoras }\end{array}$} \\
\hline & & Média & Desvio & Média & Desvio \\
\hline \multirow{4}{*}{1996} & Tamanho & 226,67 & 105,22 & 189,86 & 89,68 \\
\hline & Produtividade & $36.155,23$ & $37.456,32$ & $25.975,6$ & $28.797,67$ \\
\hline & Trabalho Qualificado & 0,25 & 0,16 & 0,22 & 0,18 \\
\hline & Firmas & 717 & & 1061 & \\
\hline \multirow{4}{*}{2001} & Tamanho & 216,60 & 101,67 & 182,77 & 84,06 \\
\hline & Produtividade & $57.628,63$ & $69.852,69$ & $34.770,88$ & $56.402,67$ \\
\hline & Trabalho Qualificado & 0,22 & 0,15 & 0,18 & 0,15 \\
\hline & Firmas & 858 & & 698 & \\
\hline
\end{tabular}

Tabela D - Características de grandes empresas

\begin{tabular}{|c|c|c|c|c|c|}
\hline \multirow[t]{2}{*}{ Ano } & \multirow{2}{*}{ Variável } & \multicolumn{2}{|c|}{ Firmas Exportadoras } & \multicolumn{2}{|c|}{$\begin{array}{l}\text { Firmas Não } \\
\text { Exportadoras }\end{array}$} \\
\hline & & Média & Desvio & Média & Desvio \\
\hline \multirow{4}{*}{1996} & Tamanho & 1291,83 & 993,32 & 1041,31 & 861,15 \\
\hline & Produtividade & $51.043,62$ & $48.669,13$ & $46.106,48$ & $33.383,27$ \\
\hline & Trabalho Qualificado & 0,24 & 0,16 & 0,33 & 0,24 \\
\hline & Firmas & 290 & & 116 & \\
\hline \multirow{4}{*}{2001} & Tamanho & 1327,76 & 1171,55 & 1110,47 & 966,54 \\
\hline & Produtividade & $81.244,78$ & $82.290,62$ & $61.714,87$ & $71.897,66$ \\
\hline & Trabalho Qualificado & 0,24 & 0,17 & 0,28 & 0,24 \\
\hline & Firmas & 258 & & 63 & \\
\hline
\end{tabular}


Tabela E - Resultados da estimação do modelo Probit para os anos de 1996 e 2001 para as firma de alto grau tecnológico

\begin{tabular}{|c|c|c|c|c|c|c|}
\hline \multirow[b]{2}{*}{ Variáveis } & \multicolumn{2}{|c|}{ Modelo 1} & \multicolumn{2}{|c|}{ Modelo 2} & \multicolumn{2}{|c|}{ Modelo 3} \\
\hline & 1996 & 2001 & 1996 & 2001 & 1996 & 2001 \\
\hline Intercepto & $\begin{array}{c}-1.6268 * * * \\
(0.0644)\end{array}$ & $\begin{array}{c}-1.4732 * * * \\
(0.0624)\end{array}$ & $\begin{array}{c}-1.1259 * * * \\
(0.0929)\end{array}$ & $\begin{array}{c}-1.4352 * * * \\
(0.0611)\end{array}$ & $\begin{array}{c}-0.7942 * * * \\
(0.1463)\end{array}$ & $\begin{array}{c}1.4696^{* * * *} \\
(0.0623)\end{array}$ \\
\hline Tam & $\begin{array}{c}0.00124 * * * \\
(0.000175)\end{array}$ & $\begin{array}{c}0.00118 * * * \\
(0.000216)\end{array}$ & $\begin{array}{c}-0.00001 \\
(0.000118)\end{array}$ & $\begin{array}{c}0.00116 * * * \\
(0.000217)\end{array}$ & $\begin{array}{c}0.000402 \\
(0.000287)\end{array}$ & $\begin{array}{c}0.00119 * * * \\
(0.000215)\end{array}$ \\
\hline $\operatorname{Tam}^{2}$ & $\begin{array}{c}-2.1 \mathrm{E}-7 * * * \\
(4.211 \mathrm{E}-8)\end{array}$ & $\begin{array}{c}-2.16 \mathrm{E}-7 * * * \\
(4,28 \mathrm{E}-05)\end{array}$ & $\begin{array}{c}-3.15 \mathrm{E}-9 \\
(1.811 \mathrm{E}-8)\end{array}$ & $\begin{array}{c}-2.15 \mathrm{E}-7 * * * \\
(4,28 \mathrm{E}-05)\end{array}$ & $\begin{array}{c}1.788 \mathrm{E}-8 \\
(1.028 \mathrm{E}-7)\end{array}$ & $\begin{array}{c}-2.18 \mathrm{E}-7 * * * \\
(4,26 \mathrm{E}-05)\end{array}$ \\
\hline Prod & $\begin{array}{l}3.67 \mathrm{E}-12 \\
(1.1 \mathrm{E}-11)\end{array}$ & $\begin{array}{c}2.81 \mathrm{E}-11 * * * \\
(1.02 \mathrm{E}-11)\end{array}$ & $\begin{array}{c}1.18 \mathrm{E}-11 \\
(1.62 \mathrm{E}-11)\end{array}$ & $\begin{array}{c}2.94 \mathrm{E}-11 * * * \\
(1.02 \mathrm{E}-11)\end{array}$ & $\begin{array}{l}-303 \mathrm{E}-13 \\
(2.13 \mathrm{E}-11)\end{array}$ & $\begin{array}{c}2.83 \mathrm{E}-11 * * * \\
(1.02 \mathrm{E}-11)\end{array}$ \\
\hline Quali & $\begin{array}{c}1.92 \mathrm{E}-10 \\
(1.53 \mathrm{E}-10)\end{array}$ & $\begin{array}{c}3.76 \mathrm{E}-10 * * \\
(1.66 \mathrm{E}-10)\end{array}$ & $\begin{array}{c}-164 \mathrm{E}-12 \\
(2.14 \mathrm{E}-10)\end{array}$ & $\begin{array}{c}3.63 \mathrm{E}-10 * * * \\
(1.67 \mathrm{E}-10)\end{array}$ & $\begin{array}{c}-565 \mathrm{E}-12 * * \\
(2.63 \mathrm{E}-10)\end{array}$ & $\begin{array}{l}3.5 \mathrm{E}-10 * * \\
(1.67 \mathrm{E}-10)\end{array}$ \\
\hline$C E$ & $\begin{array}{c}0.7861 * * * \\
(0.0997)\end{array}$ & $\begin{array}{c}0.9688^{* * * *} \\
(0.1125\end{array}$ & $\begin{array}{c}1.1044 * * * \\
(0.1363)\end{array}$ & $\begin{array}{c}0.9621 * * * \\
(0.1129)\end{array}$ & $\begin{array}{c}0.7610 * * * \\
(0.1486)\end{array}$ & $\begin{array}{c}0.9779 * * * \\
(0.1122)\end{array}$ \\
\hline$I d a$ & $\begin{array}{c}0.0111 * * * \\
(0.00198)\end{array}$ & $\begin{array}{c}0.0123 * * * \\
(0.00187)\end{array}$ & $\begin{array}{c}0.0122 * * * \\
(0.00248)\end{array}$ & $\begin{array}{c}0.0125 * * * \\
(0.00187)\end{array}$ & $\begin{array}{c}0.00840 * * * \\
(0.00314)\end{array}$ & $\begin{array}{c}0.0124 * * * \\
(0.00187)\end{array}$ \\
\hline $\operatorname{Imp}$ & $\begin{array}{c}0.8734 * * * \\
(0.0639)\end{array}$ & $\begin{array}{c}1.0594 * * * \\
(0.0749)\end{array}$ & $\begin{array}{c}0.8530 * * * \\
(0.0864)\end{array}$ & $\begin{array}{c}1.0842 * * * \\
(0.0745)\end{array}$ & $\begin{array}{c}0.8351 * * * \\
(0.1140)\end{array}$ & $\begin{array}{c}1.0362 * * * \\
(0.0755)\end{array}$ \\
\hline Prop & $\begin{array}{c}-1.01 \mathrm{E}-9 \\
(2.361 \mathrm{E}-9)\end{array}$ & $\begin{array}{c}-3.17 \mathrm{E}-9 \\
(1,99 \mathrm{E}-06)\end{array}$ & $\begin{array}{c}-672 \mathrm{E}-12 * * * \\
(2.42 \mathrm{E}-10)\end{array}$ & $\begin{array}{l}-3.69 \mathrm{E}-9 * \\
(2,01 \mathrm{E}-06)\end{array}$ & $\begin{array}{c}-1.02 \mathrm{E}-8 * * * \\
(2.717 \mathrm{E}-9)\end{array}$ & $\begin{array}{c}-3.11 \mathrm{E}-9 \\
(1,98 \mathrm{E}-06)\end{array}$ \\
\hline Inov & $\begin{array}{c}0.3401 * * * \\
(0.0577)\end{array}$ & $\begin{array}{c}0.3472 * * * \\
(0.0628)\end{array}$ & ----- & ----- & ----- & ----- \\
\hline Pat & ----- & ----- & $\begin{array}{c}0.1216 \\
(0.0836)\end{array}$ & $\begin{array}{c}0.4700 * * * \\
(0.0871)\end{array}$ & ----- & ----- \\
\hline$P D$ & ----- & ----- & ----- & ----- & $\begin{array}{c}0.3403 * * * \\
(0.1061)\end{array}$ & $\begin{array}{c}0.3314 * * * \\
(0.0623)\end{array}$ \\
\hline $\begin{array}{l}\text { Total de } \\
\text { Firmas }\end{array}$ & 3011 & 2744 & 1225 & 2744 & 720 & 2744 \\
\hline AIC & 2573.667 & 2497.045 & 1330.683 & 2497.861 & 814.955 & 2499.425 \\
\hline
\end{tabular}

Notas: (1) Erro padrão entre parênteses; (2) Nível de significância: 1\% (***), 5\% (**), 10\% (*); (3) A variável Tam representa o tamanho da firma; Prod representa a produtividade do trabalho; Quali representa a proporção de trabalho qualificado; $C E$ representa participação estrangeira no capital; Ida representa a idade da firma, Imp representa importação; Prop representa gastos com propaganda; Inov representa inovação; Pat representa patente e $P D$ representa pesquisa e desenvolvimento 
Tabela F - Resultados da estimação do modelo Probit para os anos de 1996 e 2001 para as firma de baixo grau tecnológico

\begin{tabular}{|c|c|c|c|c|c|c|}
\hline \multirow[b]{2}{*}{ Variáveis } & \multicolumn{2}{|c|}{ Modelo 1} & \multicolumn{2}{|c|}{ Modelo 2} & \multicolumn{2}{|c|}{ Modelo 3} \\
\hline & 1996 & 2001 & 1996 & 2001 & 1996 & 2001 \\
\hline & -1.9600 & $-1.6648 * * *$ & $-1.6480 * * *$ & $-1.6406^{* * *}$ & $-1.0191 * * *$ & $-1.6761 * * *$ \\
\hline Intercepto & $(0.0497)$ & $(0.0407)$ & $(0.0779)$ & $(0.0402)$ & $(0.0892)$ & $(0.0409)$ \\
\hline & $0.00204 * * *$ & $0.00242 * * *$ & 0.000155 & $0.00244 * * *$ & $0.000649 * * *$ & $0.00239 * * *$ \\
\hline Tam & $(0.000161)$ & $(0.000185)$ & $(0.000163)$ & $(0.000186)$ & $(0.000108)$ & $(0.000183)$ \\
\hline $\operatorname{Tam}^{2}$ & $\begin{array}{c}-3.75 \mathrm{E}-7 * * * \\
(5.045 \mathrm{E}-8)\end{array}$ & $\begin{array}{c}-3.38 \mathrm{E}-7 * * * \\
(3.564 \mathrm{E}-8)\end{array}$ & $\begin{array}{c}-4.17 \mathrm{E}-8 \\
(5.071 \mathrm{E}-8)\end{array}$ & $\begin{array}{r}-3.45 \mathrm{E}-7 * * * \\
(3.526 \mathrm{E}-8)\end{array}$ & $\begin{array}{c}-4.73 \mathrm{E}-8 * * * \\
(1.037 \mathrm{E}-8)\end{array}$ & $\begin{array}{r}-3.35 \mathrm{E}-7 * * * \\
(3.543 \mathrm{E}-8)\end{array}$ \\
\hline Prod & $\begin{array}{c}5.21 \mathrm{E}-12 \\
(8.16 \mathrm{E}-12)\end{array}$ & $\begin{array}{r}1.36 \mathrm{E}-11 * * \\
(6.82 \mathrm{E}-12)\end{array}$ & $\begin{array}{l}2.22 \mathrm{E}-11^{*} \\
(1.19 \mathrm{E}-11)\end{array}$ & $\begin{array}{r}1.51 \mathrm{E}-11 * * \\
(6.81 \mathrm{E}-12)\end{array}$ & $\begin{array}{c}-417 \mathrm{E}-14 \\
(1.46 \mathrm{E}-11)\end{array}$ & $\begin{array}{r}1.37 \mathrm{E}-11 * * \\
(6.84 \mathrm{E}-12)\end{array}$ \\
\hline Quali & $\begin{array}{c}1.18 \mathrm{E}-10 \\
(1.49 \mathrm{E}-10)\end{array}$ & $\begin{array}{r}5.94 \mathrm{E}-10 * * * \\
(1.45 \mathrm{E}-10)\end{array}$ & $\begin{array}{c}1.57 \mathrm{E}-10 \\
(2.07 \mathrm{E}-10)\end{array}$ & $\begin{array}{r}5.87 \mathrm{E}-10 * * * \\
(1.44 \mathrm{E}-10)\end{array}$ & $\begin{array}{c}-627 \mathrm{E}-12 * * * \\
(2.27 \mathrm{E}-10)\end{array}$ & $\begin{array}{r}5.52 \mathrm{E}-10 * * * \\
(1.45 \mathrm{E}-10)\end{array}$ \\
\hline$C E$ & $\begin{array}{c}0.6992 * * * \\
(0.1091)\end{array}$ & $\begin{array}{r}0.5404 * * * \\
\quad(0.1053)\end{array}$ & $\begin{array}{c}0.6745 * * * \\
(0.1313)\end{array}$ & $\begin{array}{r}0.5201 * * * \\
\quad(0.1055)\end{array}$ & $\begin{array}{c}0.6900 * * * \\
(0.1372)\end{array}$ & $\begin{array}{r}0.5328 * * * \\
(0.1049)\end{array}$ \\
\hline$I d a$ & $\begin{array}{c}0.0116^{* * * *} \\
(0.00157)\end{array}$ & $\begin{array}{r}0.0108^{* * * *} \\
(0.00131)\end{array}$ & $\begin{array}{c}0.0200 * * * \\
(0.00206)\end{array}$ & $\begin{array}{r}0.0109 * * * \\
(0.00131)\end{array}$ & $\begin{array}{c}0.00899 * * * \\
(0.00217)\end{array}$ & $\begin{array}{r}0.0109 * * * \\
(0.00131)\end{array}$ \\
\hline $\operatorname{Imp}$ & $\begin{array}{c}0.9265 * * * \\
(0.0536)\end{array}$ & $\begin{array}{r}1.0582 * * * \\
(0.0616)\end{array}$ & $\begin{array}{c}0.9311 * * * \\
(0.0685)\end{array}$ & $\begin{array}{r}1.0716^{* * * *} \\
(0.0615)\end{array}$ & $\begin{array}{c}0.8137 * * * \\
(0.0752)\end{array}$ & $\begin{array}{r}1.0282 * * * \\
(0.0619)\end{array}$ \\
\hline Prop & $\begin{array}{c}1.649 \mathrm{E}-9 \\
(1.706 \mathrm{E}-9)\end{array}$ & $\begin{array}{c}2.437 \mathrm{E}-9 * \\
(1.321 \mathrm{E}-9)\end{array}$ & $\begin{array}{c}3.85 \mathrm{E}-11 * * * \\
(9.7 \mathrm{E}-11)\end{array}$ & $\begin{array}{c}2.418 \mathrm{E}-9 * \\
(1.319 \mathrm{E}-9)\end{array}$ & $\begin{array}{c}1.084 \mathrm{E}-9 \\
(2.901 \mathrm{E}-9)\end{array}$ & $\begin{array}{c}2.348 \mathrm{E}-9 * \\
(1.319 \mathrm{E}-9)\end{array}$ \\
\hline Inov & $\begin{array}{c}0.3195 * * * \\
(0.0467)\end{array}$ & $\begin{array}{r}0.3370 * * * \\
(0.0477)\end{array}$ & ----- & ----- & ----- & ----- \\
\hline Pat & ----- & ----- & $\begin{array}{c}0.1927 * * * \\
(0.0669)\end{array}$ & $\begin{array}{r}0.5001 * * * \\
\quad(0.0752)\end{array}$ & ----- & ----- \\
\hline$P D$ & ----- & ----- & ----- & ----- & $\begin{array}{c}0.2301 * * * \\
(0.0760)\end{array}$ & $\begin{array}{r}0.3890 * * * \\
\quad(0.0463)\end{array}$ \\
\hline $\begin{array}{l}\text { Total de } \\
\text { Firmas }\end{array}$ & 6287 & 6988 & 2190 & 6988 & 1505 & 6988 \\
\hline AIC & 3854.875 & 5319.026 & 2048.622 & 5323.631 & 1716.817 & 5299.095 \\
\hline
\end{tabular}

Notas: (1) Erro padrão entre parênteses; (2) Nível de significância: 1\% (***), 5\% (**), 10\% (*); (3) A variável Tam representa o tamanho da firma; Prod representa a produtividade do trabalho; Quali representa a proporção de trabalho qualificado; $C E$ representa participação estrangeira no capital; Ida representa a idade da firma, Imp representa importação; Prop representa gastos com propaganda; Inov representa inovação; Pat representa patente e $P D$ representa pesquisa e desenvolvimento 